\title{
What is Local Knowledge? Digital Humanities and Yuan Dynasty Disasters in Imperial China's Local Gazetteers*
}

\author{
Dagmar Schäfer ${ }^{1 \star}$ (D), Shih-pei Chen ${ }^{1}$ and Qun Che $^{2}$ \\ ${ }^{1}$ Max Planck Institute for the History of Science and ${ }^{2}$ Shanghai Jiaotong University. \\ *Corresponding author. Email: dschaefer@mpiwg-berlin.mpg.de
}

(Received 13 March 2020; revised 11 May 2020; accepted 14 May 2020)

\begin{abstract}
This paper focuses on the historical politics of disaster records in Chinese local gazetteers (difangzhi 地方志). Using records of mulberry crop failures as examples, the authors ask how gazetteer editors collated Yuan disaster records-initially collected to help prevent disasters and authorize the legitimacy of dynastic rule-in gazetteers and, in so doing, made them into 'local' knowledge. Digital humanities methods allow for both qualitative and quantitative analyses, and the authors deploy them to demonstrate how, in structured texts like the Chinese local gazetteers, they could help combine close reading of specific sections and larger-scale analysis of regional patterns. In the first part, the authors show how disasters were recorded in a Yuan Zhenjiang gazetteer to facilitate taxation and disaster prevention locally-a strategy rarely traceable in subsequent gazetteers until the Qing. In the second part, the authors shifted their perspective to the historical accumulation of data and what that reveals about the reception of Yuan disasters: whereas local gazetteers from the north generate long chronologies of mulberry disasters from the Ming to the Qing, others depict the south as disaster-free.
\end{abstract}

Keywords: local gazetteers; historical disasters; mulberry crop failures; digital humanities; Big Data

According to its local gazetteer (Dongming xian zhi) of 1673, disasters hit Dongming county in Hebei hard during the era of Mongolian Yuan rule (1271-1368). In 1301 alone the gazetteer lists three events: a plague of insects wiped out the mulberry crop during the fourth lunar month, and a drought in the sixth lunar month was followed

${ }^{\star}$ This article results from collaborative work and datasets collated by many hands. Contributions are indicated in footnotes. We would like to thank Franz Maulshagen, Sun Mengmeng, Xu Chun, Masato Hasegawa, Alexis Lycas, Marianna Szczygielska, Peter Bol, and the two reviewers for commenting on earlier versions of this article. Part of this article was conceptualized while one of the authors, Dagmar Schäfer, was at the Institute for Advanced Studies, Princeton, and we would like to express our appreciation for this support as well.

(c) The Author(s), 2020. Published by Cambridge University Press. This is an Open Access article, distributed under the terms of the Creative Commons Attribution-NonCommercial-NoDerivatives licence (http://creativecommons.org/ licenses/by-nc-nd/4.0/), which permits non-commercial re-use, distribution, and reproduction in any medium, provided the original work is unaltered and is properly cited. The written permission of Cambridge University Press must be obtained for commercial re-use or in order to create a derivative work. 
by a flood in the seventh. In the fifth month of 1308 another insect plague devoured all of the mulberry leaves. In the third month of 1314, frost destroyed mulberry and fruit trees as well as grain seedlings. ${ }^{1}$ One of thousands of reports in China's historical literature, the disasters listed in Dongming's local gazetteer have contributed to narratives of China's political and climate change over the centuries. Since the Ming dynasty (13681645) scholars have interpreted these reports as evidence that the Mongolian rulers' war policies and inability to rule China had upset heavenly patterns and nature's balance in China's north. ${ }^{2}$ In the late 1920s, one of the first generation of China's western-trained scientists in climate research, Zhu Kezhen 笈可楨 (1890-1974), put such ideas in scientific terms, integrating Yuan dynastic disasters into his global model of climate and temperature fluctuations. ${ }^{3}$

The story might well have ended here, as mid-twentieth-century researchers first ignored Zhu's scientific interventions and then dismissed them quickly. ${ }^{4}$ The pattern of geography and the chronology of disasters as laid out in this research proved tenacious, however, even as later historians and scientists hotly debated the added impact of wars, migration, and technological change. In China's rich historical literature, the local gazetteers-approximately ten thousand titles covering the core regions of imperial governance-have been an important source for research that lent "local" credibility to research on longue-durée geographies of environmental change. Shortly before his death, Zhu Kezhen himself contended that, "apart from meteorological measurements with instruments, local gazetteers provide the most reliable historical data on a region's climate." ${ }^{5}$ By then, Zhu could draw on the established field of "local gazetteer studies" (fangzhi xue 方志學), which Liang Qichao 梁啟超 (1873-1929) had established in the 1920 s. $^{6}$ Treated as "local realities that editors and authors recounted impersonally in an

\footnotetext{
${ }^{1}$ Yang Risheng 楊日升, (Kangxi) Dongming xian zhi (康熙) 東明縣志 (1673; repr. in Beijing daxue tushuguan xijian fangzhi congkan 北京大學圖書館藏稀見方志叢刊. Beijing: Guojia tushuguan, 2013), “Zazhi” 雜志 7.6a.

${ }^{2}$ The scholar-official and minister in charge of agriculture, Xu Guangqi (1562-1633), a disciple of the Jesuit scholar Matteo Ricci (1552-1610), commented on the biased agronomical policies of the Yuan in the north; Xu Guangqi 徐光啓, “Nongzheng quanshu” 農政全書 in Xu Guangqi quanshu 徐光啓全書, vol. 6-8 (Shanghai: Shanghai guji, 2010), "Huangzheng” 荒政 44.988. For a summary of the Yuan and Ming era in light of weather events see Timothy Brook, The Troubled Empire: China in the Yuan and Ming Dynasties (Cambridge, MA: Belknap Press 2010), 50-73.

${ }^{3}$ Zhu Kezhen 竺可楨, “Nan Song shidai woguo qihou zhi chuaice” 南宋時代我國氣候之揣測, Kexue 2 (1925), 151. Zhu used the records of the numbers of cold years in Tushu jicheng: Shuzhengdian: Hanshu yibu 圖書集成: 庶徵典: 寒暑異部 to confirm the cold weather from the thirteenth to the fourteenth centuries. This conclusion never changed until his final temperature model in 1973. In a 1925 paper (English version 1926) he noted that "it is well known to the Chinese historians that during the Yuan Dynasty the Mongol invaders demolished the drainage system in the Yellow River valley." See Zhu Kezhen 筑可楨, “Zhongguo lishi shang qihou zhi bianqian” 中國歷史上氣候之變遷, Dongfang zazhi 22 (1925), 84-99. See also Zhu Kezhen 笈可楨, "Lun woguo qihou de ji ge tedian jiqi yu liangshi zuowu shengchan de guanxi” 論我國氣候的幾個特點及其與糧食作物生產的關係，in Zhu Kezhen wenji 竺可楨文集 (Beijing: Kexue, 1979), 460, 472; Co-Ching Chu, "Climatic Pulsations during Historic Time in China," The Geographical Review 16 (1926), 274-82.

${ }^{4}$ The "ice age" was a popular theme in the 1970s, and Zhu's model attracted some international attention during the 1970s and 1980s. Sun Mengmeng 孫萌萌 and Jiang Xiaoyuan 江曉原, “Zhu Kezhen qihou bianqian sixiang de laiyuan” 竺可楨氣候變遷思想的來源, Ziran kexueshi yanjiu 35 (2018), 104-16.

${ }^{5}$ Zhu Kezhen 竺可楨, “Zhongguo jin wuqian nian lai qihou bianqian de chubu yanjiu” 中國近五千年 來氣候變遷的初步研究, in Zhu Kezhen wenji, 486.

${ }^{6}$ Liang Qichao 梁啟超, Zhongguo jin sanbainian xueshushi 中國近三百年學術史 (Shanghai: Shanghai sanlian shudian, 2006), 356-72.
} 
explanatory manner,"7 local gazetteer data thus supported historians of the environment, specialists in cultural climate studies, and scientists alike in claiming that "1230-60 might have been the warmest thirty years in the ensuing two thousand years in eastern and middle China," with 1260 marked as "the year after which the weather started to turn cold, culminating in a Little Ice Age around 1320."8

This paper queries the reliably "local" nature of local gazetteers with regard to their accounts of disasters. At the core of this investigation stand three interrelated debates about local knowledge, environmental change, and the use of digital humanities (henceforth $\mathrm{DH}$ ) in historical research. Beginning in the twentieth century, historians of disasters in China have embraced local sources to inquire into the regional effects of China's imperial-disaster politics and produce the thick descriptions that Clifford Geertz introduced to anthropology to "gain access to the conceptual world in which [the participants] live." In the study of Chinese history, local gazetteers offered an alternative account that seemed presumably more concrete, locatable, and immediate in character than those of dynastic histories and court historiography and that revealed the locally diverse effects of a global phenomenon beyond culture, economy, societal configuration, and intellectual worlds.

Historians know that local sources do not necessarily equate with local events, local information, or local knowledge. The records of weather events and disasters in China's local gazetteers are the product of a long historical dialectic between local and imperial knowledge- and space-making, ${ }^{10}$ in which any unpredicted and anomalous events, but especially those causing harm to the people and the state, were indicators of the Mandate of Heaven (tianming 天命) and dynastic legitimacy. ${ }^{11}$ Since at least the Western Han (206 BCE-9 CE), diviners, astronomers, and astrologers forecast the weather, prognosticated, and interpreted such events. Local officials, for their part, observed and managed earthquakes, floods, droughts, and insect plagues and tried to cope.

The thousands of datasets in Local Gazetteers that Big Data analysts since Zhu Kezhen have interpreted as quantitative evidence of a period of historical change are seen by historians as the "local" residue of a continuous dynamic practice in what we term a "genre of scale," because in an almost inverse relation we see how with increasing numbers local gazetteers included disaster reports in a decreasing number of categories as editors followed genre-specific guidelines ( fanli 凡例). ${ }^{12}$ Starting as a systemic

\footnotetext{
${ }^{7}$ Luo Lin 羅琳, “Zhongguo gudai difangzhi zhi zaiyi jilu” 中國古代地方志之災異紀錄, in 2004 Difang wenxian guoji xueshu yantaohui lunwenji2004 地方文獻國際學術研討會論文集, edited by Guojia tushuguan gujiguan 國家圖書館古籍館 (Beijing: Beijing tushuguan, 2006), 295.

${ }^{8} \mathrm{Ge}$ Quansheng 葛全勝, Zhongguo lichao qihou bianhua 中國歷朝氣候變化 (Beijing: Kexue, 2011), 167, 439. This assessment was based on 200 phenology records over 2,000 years.

${ }^{9}$ Geertz, who drew on Gilbert Ryle (1900-1976) inspired in particular an increased interest in historical anthropology. Clifford Geertz, "Thick Description: Toward an Interpretive Theory of Culture," in The Interpretation of Cultures: Selected Essays, edited by Clifford Geertz (New York: Basic Books, 1973), 17, 24.

${ }^{10}$ We define space-making here as the traditional practices and theories that historical actors used to understand, define, and create geopolitical entities. Felix Driver, "Making Space: Territorial Themes in the History of Science', a Conference Organized by the British Society for the History of Science, Held at the University of Kent, Canterbury, 28-30 March 1994," Ecumene 1.4 (1994), 386-90.

${ }^{11}$ Andrea Janku, "Heaven-sent Disasters' in Late Imperial China: The Scope of the State and Beyond," in Natural Disasters, Cultural Responses: Case Studies toward a Global Environmental History, edited by Christof Mauch and Christian Pfister (Lanham, MD: Lexington Books, 2009), 233-65, 239.

${ }^{12}$ While there was no known top-down fanli issued in Song and Yuan, many local gazetteer editors oriented their compilations based on earlier templates or followed up on orders by the central government to systematically collect certain datasets such as on taxes, geographical features, resources. Court or provincial
} 
bureaucratic practice in the tenth century, local gazetteers had by the twentieth century grown to ten thousand existing titles covering diverse scholarly and state-related concerns in single titles as well as continuously re-edited issues. ${ }^{13}$ The "footprint" of the local gazetteers expanded and shrunk depending on changing territory ruled by the Liao (916-1125), Xi-Xia (1038-1227), Song (960-1279), Jin (1115-1234) and Yuan (1271-1368). In environmental history terms, disaster reports in local gazetteers can be understood as the result of a central state policy that spurred individuals to gather data, not unlike the historical weather data that Austrian Habsburg officials collected in the eighteenth century and upon which scientists in the nineteenth century developed dynamic climatology. ${ }^{14}$ Unlike the Habsburg weather data, the data in local gazetteers were shaped by almost a millennium of scholarly and bureaucratic cultures that used and re-interpreted earlier records of previous generations while continuing to report disasters of their own era.

As historians of science, our perspective in this article is to ask how disasters were understood locally, made a category of local (administrative) practices, and became local knowledge. Our major concern is to complement the rich research on China's history of disasters and its politics, with an analysis of the politics of (disaster) data in local gazetteers. What interests us methodologically in this article is how the view, both of China's history of disasters and of the Yuan, changes when we are able to incorporate into the analysis the large-scale development of local gazetteers as a genre and the specific local conditions and individual authorial or editorial choices. Unlike historians of environment and cultural climate studies who use historical climate data to explain history, we have combined quantitative textual data (on disasters) with qualitative contextual studies (of disaster politics and discourses around the Mandate of Heaven) to query the nature of historical data on disasters; in this article we use DH methods to undertake qualitative research on a large scale. First, along with other authors in this issue, we are interested in practices of distance-reading, ${ }^{15}$ asking what happens when we pursue qualitative textual analysis with a quantitative orientation. Choosing a genre-specific (that is, local gazetteers) view, we look for the strategies that local gazetteer editors employed to gather disaster data and organize and interpret this information; we ask how common or idiosyncratic approaches to disaster data collection were and what knowledge readers may have expected to gain from local gazetteers. These questions, when asked on a large scale, constitute a quantitative approach to qualitative historical work-one that reflects on historical practices of organizing content and protocols of reading-which can help us understand the value and reliability of claims about disasters made in the gazetteers and thus which claims we should be wary of using as a base for extrapolation. We will at least know what we do not know.

governments started to issue generic editorial regulations in the Ming. See Wu Zongqi 吳宗器, Shenxian zhi 莘縣志 (1515; repr. in Tianyige cang Mingdai fangzhi xuankan 天一閣藏明代方志選刊. Shanghai: Shanghai guji chubanshe, 1964), “Zuanxiu zhishu fanli” 纂修志書凡例, 1a-3b.

${ }^{13}$ Peter K. Bol, "The Rise of Local History: History, Geography, and Culture in Southern Song and Yuan Wuzhou," Harvard Journal of Asiatic Studies 61 (2001), 37-76. See also James M. Hargett, "Song Dynasty Local Gazetteers and Their Place in The History of Difangzhi Writing," Harvard Journal of Asiatic Studies 56 (1996), 405.

${ }^{14}$ Deborah R. Coen, Climate in Motion: Science, Empire, and the Problem of Scale (Chicago: University of Chicago Press, 2018).

${ }^{15}$ See Franco Moretti, Distant Reading (London: Verso, 2013). For the methods, see his earlier publication Franco Moretti, Graphs, Maps, Trees: Abstract Models for a Literary History (London: Verso, 2005). 
The shift of perspective proposed in this article-from seeing disasters as historical events to seeing them as discourse and subject of local knowledge as epistemic practice -brings up a second DH-related issue about how digitized tools can help assess the qualitative implications of quantitative phenomena. We are interested in how data on disasters historically reflected and exerted power and control in the Foucauldian sense (1) as the material condition of the actual event, (2) as an affordance for a discourse about disasters and (3) from an a posteriori view. We thus explore our gazetteer data in relation to Yuan politics and disaster management practices, on the one hand, and Yuan's legitimacy as seen in texts whose transmission is partial and influenced by a literati mindset on the other. We peruse the layers of text history and reception, observe the ways in which generations of Ming and Qing local gazetteer editors, collating such data, reflected on the Yuan dynasty and its disasters, and ask whether we can identify a point of view generated by local gazetteers as a genre.

To do this in a field as complex as disasters and climate, we singled out mulberry-related crop failures (sangzai 桑災). Zhu Kezhen, like nineteenth-century Habsburg climatologists, included mentions of the impact of weather events on plant growth. He systematically inferred changes in temperature by correlating modern scientific understandings of the relation between seasonal plant growth and temperature with historical observations on anomalous plant growth (unusual fruiting, seeding, flowering, freezing, and thawing). ${ }^{16}$ Although the practice of phenology is still in use today, modern historical disaster studies - which have focused almost exclusively on earthquakes, floods, droughts, or famines-have ignored agricultural crop failures, on the grounds that they were mainly political and economic events that were often a consequence of corrupt practices. ${ }^{17}$ Indeed, disasters involving the mulberry crop were both political and economic. Mulberry leaves were the major fodder of the silkworms necessary to produce the textiles that constituted a large part of the Yuan dynastic economy, and hence they played a major role in the politics of tax relief whenever disaster struck. Just as our modern world defines disasters in relation to how humans wish to make use of lands (as habitat and resource), fourteenth-century state actors and producers perceived moriculture crop failure as a major "disaster" $(z a i \text { 災 })^{18}$ because of the mulberry tree's important agricultural and economic role.

\footnotetext{
${ }^{16} \mathrm{Zhu}$ understood "the study of the times of things" (wuhou xue 物候學), which equates to the later phenology or chronobiology, within the Chinese tradition of defining cyclical and seasonal phenomena calendrically and for medicinal purposes as Sun Mengmeng, The Construction of "Ancient Chinese Climatology" in the Practice of Phenology (forthcoming) points out. Gong Gaofa 龔高法, Zhang Piyuan 張不遠, and Wu Xiangding 吳祥定, Lishi shiqi qihou bianhua yanjiu fangfa 歷史時期氣候變化研究方 法 (Beijing: Kexue, 1983), 20-21 note that in correlation to international debates, he emphasized the great potential of the quite continuous historical records of China for scientific climate studies. For the international, European debate see also Coen, Climate in Motion, 96.

${ }^{17}$ Harry F. Lee and David D. Zhang, "A Tale of Two Population Crises in Recent Chinese History," Climatic Change 116 (2013), 285-308. Literature in general concentrates on "natural" disasters and makes a note of famines, yet largely ignores mentions of crop failures. For an example in Chinese-language environmental history, see Luo Lin, "Zhongguo gudai difangzhi zhi zaiyi jilu," 295, who concentrates on natural (ziran 自然) disasters such as water and fire disasters as "objective reality" (keguan shishi 客觀事實).

${ }^{18}$ We will henceforth use the English term disaster mostly as a summarizing generic term. Chinese disaster terminology emphasized accountability in terms of morality and finances, as does the English term "disaster" that signifies a moment of substantial destruction and distress or the Italian/Latin term disastrum that identified an evil influence of a star; see Webster's Third New International Dictionary of the English Language Unabridged (Chicago: Encyclopaedia Britannica, 1961), 643. Different political and
} 
We begin with an exercise in a close reading of one local gazetteer to see how Yuan imperial politics related to local practices of cultivating mulberries for silk production (henceforth moriculture) ${ }^{19}$ and what role disasters play therein. For this we use one of the few still-extant Yuan local gazetteers that recounts disaster events in Zhenjiang, situated in Southern China on the Yangtze River east of Nanjing. Zhenjiang's local gazetteers have bolstered in two ways the view that the north was subject to repeated disasters while moriculture was evolving in the south: first, Yu Xilu 俞希魯 (1279-1368), the Yuan editor, testifies that mulberry was cultivated by the Yuan. Second, none of Zhenjiang's various local gazetteer editions record any moriculture disasters.

\section{Localizing Imperial Politics: Mulberry Trees and Taxes in Southern Zhenjiang}

"Sang: its leaves feed the silkworm. Several kinds exist. Blossoming sang have small and thin leaves," ${ }^{20}$ noted Yu Xilu in Zhenjiang's local gazetteer published in 1332. Yu, whose lifespan coincided almost exactly with that of the short-lived Yuan dynasty, had a career that reflects the ambiguous characteristics historians have attributed to his times: the descendant of a Song official, he served the Mongolian Yuan conquerors as a teacher and negotiated as a member of the elite and erudite scholar-official between the local and central state and court in various, mostly local, administrative roles. ${ }^{21}$

epistemological implications inform notions of prevention or damage control throughout different dynasties and we would like to thank Chun Xu for pointing this out. Chinese literati and administrators distinguished "unexpected" deviations from normalcy as zai 災 (which denotes a raging fire) from disasters causing anxiety (huan 患) or damage (hai 害), or auspicious or inauspicious signs/omen (xiang 祥) for the legitimacy of rule etc. In lieu of research on such terminological changes during the Song and Yuan, see the discussion of Ming uses of terminology in water management in Chun $\mathrm{Xu}$, "Reaping the Benefits of Water: A History of Water(s) in Ming Yunnan" (PhD diss., Heidelberg University, 2018).

${ }^{19}$ We introduce moriculture here as a summarizing technical term for the sum of knowledge (i.e. sciences) and practices of cultivating plants for the purpose of silk production. Morus (mulberry) identifies the Linnean genus of the most common plants used for feeding the silkworm (Morus nigra, Morus alba, Morus laevigata, and Morus latifolia); Linnean students traveling to China in the nineteenth century introduced the term. Alexandra Cook, "Linnaeus and Chinese Plants: A Test of the Linguistic Imperialism Thesis 2010," Notes and Records: The Royal Society Journal of the History of Science 64 (2009), 121-38. This modern identification does not pay respect to the broader range of plants that Chinese farmers identified as sang 桑 or used to feed silkworms such as the sugarcane or elm tree (zhe 柘).

${ }^{20} \mathrm{Yu}$ Xilu 俞希魯 and Tuoyin 脫因, Zhishun Zhenjiang zhi 至順鎮江志 (1842; repr. in Song Yuan fangzhi congkan 宋元方志叢刊. Beijing: Zhonghua shuju, 1990), “Tuchan”土產 4.35a. By the Qing era, Ruan Yuan 阮元 (1764-1849) still noted that the authorship for this gazetteer was unclear. Ruan Yuan 阮元, preface in “Jiading Zhenjiang zhi 嘉定镇江志," edited by Lu Xian 盧憲 in 1213, revised and edited by Shi Mijian 史彌堅 in 1842 (1842; repr. in Song Yuan fangzhi congkan 宋元方志叢刊. Beijing: Zhonghua shuju, 1990), “Xu” 序 2b. For an analysis of the authorship of Yu see Yang Jiqing 楊積慶, “Yu Xilu qiren: Zhishun Zhenjiang zhi de zuozhe” 俞希魯其人: “至順鎮江志”的作者, Zhenjiang shizhuan xuebao (Shehui kexue ban) 1987.4, 98-100.

${ }^{21}$ Sheng Quan 盛銓 and Huang Bingkui 黄炳奎, Chongren xian zhi 崇仁縣志 (1873; repr. in Zhongguo difangzhi jicheng 中國地方志集成. Nanjing: Fenghuang chubanshe, 2013), “Yiwen zhi: Wenzheng”藝文 志: 文徵 9.1a. For an analysis of epitaphs and other tomb inscriptions, see Shang Yanbin 尚衍斌, "Yuandai Weiwu'er nongxue jia Lu Mingshan shiji zai tantao” 元代畏元兒農學家魯明善事蹟再探討, Zhongguo bianjiang shidi yanjiu 22 (2012), 77-89. See also Yu Ji 虞集, “Jingzhoulu Daluhuachi Lu gong shendao bei” 靖州路達魯花赤魯公神道碑, in Yu Ji 虞集, Daoyuan leigao 道園類稿 (Yuan keben 元刻本 [Yuan dynasty print], n.d.; repr. in Zhonghua zaizao shanben 中華再造善本. Beijing: Guojia tushuguan, 2013), “Shendao bei” 神道碑 43.44a-49b. 
Most of what is known about Yuan-dynasty Zhenjiang was penned by $\mathrm{Yu}$-his was the second of a set of four still-extant Zhenjiang local gazetteers-for which he consulted historical geographic records and contemporary administrative sources. ${ }^{22}$ Historians have seen his texts, rich in detail about local economic and social conditions, as the work of a well-informed local who aimed to serve the interests of the ruling class. ${ }^{23}$ $\mathrm{Yu}$ relates local customs, social configurations, architectural features, landscapes, and taxes. He describes the form and function of sang, the plant, in the chapter on "local products." ${ }^{24}$ How does Yu's approach fit into the information politics of Yuan times?

Sang was a central political theme by 1332 and well-covered in writing. Yuan Chinese and later Ming voices attribute a voracious appetite for silk to the ruling elite of the Yuan, but also emphasize that this elite was much less familiar than its predecessors with all the processes relevant to its production. ${ }^{25}$ Qubilai Khan (reigned 1260-94) invested in agriculture and silk by strengthening institutions such as the Board of Agriculture (Sinongsi 司農司). ${ }^{26}$ By 1332, Yu could look back at a continuous, intensive and increasingly systematic campaign by the state and elites to circulate information about sang. ${ }^{27}$ The Compendium on Agriculture and Mulberry Plants (Nongsang jiyao 農桑輯要) was a re-compilation of earlier texts. ${ }^{28}$ Over 10,000 copies of this

\footnotetext{
${ }^{22}$ Preface to Zhishun Zhenjiang zhi 至順鎮江志. The other three Local Gazetteers of Zhenjiang are of the Song Jiading era (1213), the Qing Kangxi era (1685) and the Qing Qianlong era (1750). Two editions of the Qianlong Zhenjiang fu zhi are in LoGaRT.

${ }^{23}$ Chen Lijian 陳立健, “Zhishun Zhenjiang zhi suo zai Zhenjiang Dishisi-youguan Yuandai Dishisi yu Menggu zixue de yidian zuozheng” ‘至順鎮江志” 所載鎮江帝師寺一有關元代帝師寺與蒙古字學的一 點佐證, Zhongguo zangxue 2004.4, 59-62. For comparative studies on Yuan Local Gazetteers see e.g. Yin Guangzhong 殷光中, “Jiading Zhenjiang zhi, Zhishun Zhenjiang zhi tiyao” '嘉定镇江志, ‘至顺镇 江志 ‘提要, Jiangsu shelian tongxun 1983.04, 41-42 and Fu Guangsen 傅光森, “Zhizheng Jinling xinzhi yu Zhishun Zhenjiang zhi zhi bijiao: yi zhengzhi ji renwu jizai wei li” “至正金陵新志“與“至順鎮江志'之 比較: 以政制及人物記載為例, Xingda renwen xuebao 32 (2002), 767-84.

${ }^{24}$ Yu Xilu, Zhishun Zhenjiang zhi, “Tuchan” 土產 4.33a-36b: “桑葉司飼䖯 有數種 有花者葉小而薄.”

${ }^{25}$ Most prominently in dynastic historiography: “其俗不待蛊而衣 不待耕而食 初無所事焉” in Song Lian 宋濂, Yuan shi 元史 (Beijing: Zhonghua shuju, 1976), 93.2354. An exemplary Song scholar, Qin Guan 秦觀 (1049-1100) compiled a very short Book about the Silkworm (Can shu 䖝書) while in mourning.

${ }^{26}$ Wang Pan 王磐 mentions in the preface of Nongsang jiyao 農桑輯要 that the compilation happened with the institutionalization of the Ministry of Agriculture ( $D a$ Sinongsi 大司農司) and required almost six years for completion, which Zeng Xiongsheng has dated to 1272. See Zeng Xiongsheng 曾雄生, Zhongguo nongxue shi 中國農學史 (Fuzhou: Fujian renmin chubanshe, 2008), 430-39, 432.

${ }^{27}$ The posts were stopped in the fourteenth year (1277) and the task of advising on agriculture was handed over to the Surveillance Commission (Ancha si 按察司). In the eighteenth year (1281) then the “Courtyard for Agricultural Policies" (Nongzheng yuan 農政院) was inaugurated with six officials which again changed the name two years later and assigned one Mongolian head (Daluhuachi 達魯花赤, rank), one Chinese supervisor (Wunong shi 務農使, rank) and two administrators (tongzhi 同知, rank). Ranking, appointments, and the local office's denomination were altered several times between 1270 and 1286 to reflect these changes. A reform of the system of agri- and moriculture (nongsang zhi zhi 農桑 之制) was issued in 1340. See Song Lian, Yuan shi, 93.2354.

${ }^{28}$ Nongsang jiyao 農桑輯要, edited by Sinongsi 司農司 (1339; repr. in Zhonghua zaizao shanben 中華 再造善本. Beijing: Guojia tushuguan, 2013), 6 juan, and 28 sections. The Nongsang jiyao replicates 20,000 characters of the Important Arts for Common People (Qimin yaoshu 齊民要術) written by Jia Sixie 賈思茄 (ca. 6th century) which thus makes up a third of the final Nongsang jiyao. See Zeng Xiongsheng, Zhongguo nongxue shi, 433. It furthermore quotes the sericulture sections and contents of ten other books mostly compiled by Song and Jurchen-Jin authors. For an analysis of the different approaches of the works on mori- and sericulture see Chuan-hui Mau, "Les progrès de la sériciculture sous les Yuan $\left(\mathrm{XII}^{\mathrm{e}}-\mathrm{XIV}{ }^{\mathrm{e}}\right.$
} 
compendium were printed in the first run; it was reprinted in 1315, 1322 and $1332 .^{29}$ There were other works. The Chinese literatus Wang Zhen 王禎 (1271-1368) wrote on contemporary practices and methods in $1312 .{ }^{30}$ The local son of the famous and influential Buddhist Uighur translator Karunadasa, Lu Mingshan 魯明善, published a tract titled Synopsis of Agriculture and Mulberry, Clothing and Food (Nongsang yishi cuoyao 農桑衣食撮要) in 1314, after having served in several local posts in Jingzhou (Hubei) and Anfeng (Jiangsu) in central and southeastern China. ${ }^{31}$ Imagery was abundant, too. The Yuan court recompiled Illustrations of Tilling and Weaving (Gengzhi tu 耕織圖), previously sponsored by the Song court, and ordered public dissemination of individual scroll-paintings of landscapes such as the Illustrations with Explanations of Mulberry Tree Plantations (Zaisang tushuo 栽桑圖說). ${ }^{32}$ Wang Zhen had his work illustrated with images of tools and plants.

Yuan elites went beyond literary dissemination. The government dispatched vocational trainers to places that books would not reach. Huang Jie 黃玠 (fourteenth century), for example, called upon his peers to include mulberry trees in their flower gardens for educational purposes. ${ }^{33}$ All possible means and media were employed: print, images, and oral education. The Compendium on Agriculture and Mulberry Plants' editors at the court's Hanlin academy “newly added” (xintian 新添) contents on new plants and repeatedly duplicated information, such as "how to use [mulberry]

siècles) d'après le Nongsang Jiyao," in Travail et savoirs techniques dans la Chine prémoderne. Revue de Sydenthèse, edited by Éric Brian (Paris: Springer, 2010), 194-216. As Wang Yuhu 王毓瑚, “Guanyu Nongsang jiyao" 關於'農桑輯要, Beijing nongye daxue xuebao (1956.2), 77-84 has noted, the Compendium does not include Chen Fu's 陳敷 Nongshu 農書, which primarily tackles the southern regions. Southern books had not yet percolated to the north, with the exception of the Suishi guangji 歲時廣記, compiled by the Southern Song contemporary Chen Yuanliang 陳元靚. Also missing is Han Yanzhi's 韓彥直 book Yongjia julu 永嘉橘錄 or Wang Zhuo’s 王灼 Tangshuang pu 糖霜譜, which suggests that the Nongsang jiyao was produced before the Mongols had any access to Southern Song literature, i.e. before 1279, and that later authors, such as Wang Zhen, saw a need for updates.

${ }^{29}$ Xiao Kezhi 肖克之, “Nongsang jiyao banben shuo” ‘農桑輯要’ 版本說, Gujin nongye 2000.4, 49-50.

${ }^{30}$ Wang Zhen 王禎, Nongshu 農書 (1530; repr. in Zhonghua zaizao shanben 中華再造善本. Beijing: Guojia tushuguan, 2013).

${ }^{31}$ As a survey of book catalogues throughout the Ming shows, this book exists under various titles. Lu Mingshan served in Jingzhou as a foreign expert local official (Daluhuachi 達魯花赤) and was appointed to Anfeng province as surveillance official in 1311. His career is described in the tomb stele by Yu Ji, “Jingzhoulu Daluhuachi lu gong shendao bei," “Shendao bei” 43.45b. See Yang Lian 楊镰, “Lu Mingshan shiji gouchen” 魯明善事迹勾沉, Xinjiang daxue xuebao 1985.3, 91-96. A biography of Lu's father Karunadasa (Jialunadasi zhuan 迦鲁纳答思传) is included in Song Lian, Yuan shi, 134.3260-61. See Angela von Driesch and Herbert Franke, "Niu-ching da-ch'üan: Ein altchinesisches Buch über tierärztliche Behandlungen von Rinderkrankheiten,” Monumenta Serica 40 (1992), 121-28.

${ }^{32}$ Song Lian, Yuan shi, 26.585. Huai Jingqiu 隗靜秋, Wu Rugong 吳如功, “Yuandai Zhejiang chubanye shulüe“元代浙江出版業述略, Xuelilun 18 (2012), 144-46. All dynasties since the Han compiled some illustrated guidance for tilling and weaving, even though most have not survived. Roselyn Lee Hammers, Pictures of Tilling and Weaving: Art, Labor, and Technology in Song and Yuan China (Hong Kong: Hong Kong University Press 2011), emphasizes the shifting political emphasis of these illustrations with Song ideals of governance and a "well-ordered" state. She identifies poetry as contemporary and cautions on the dating of images which she considers as transmissions of later versions. As Yang Dezhong 楊德忠 pinpointed, the Yuan utilizied such imagery purposefully; see Da Yuan qixiang: Yuandai huangquan yishixia de shuhua huodong jiqi zhengzhi yihan 大元氣象: 元代皇權意識下的書畫活動及其政治意涵 (Beijing: Shangwu yinshuguan, 2018), 219-23.

${ }^{33}$ Huang Jie 黃玠, “Zhong hua yin” 種花吟, in Bianshan xiaoyin yinlu 弁山小隱吟錄 (1934; repr. in Siming congshu 四明叢書. Yangzhou: Guanglin shushe, 2006) 2.50b. 
leaves," from varied sources that were relevant to the beginner cultivating mulberry trees and breeding silkworms. ${ }^{34}$

Although the elites of that time emphasize the state-driven top-down nature of such education, it was not a one-way street. Lu Mingshan recorded proverbs and folk sayings, most likely sourced from farmers. ${ }^{35}$ The Daoist and painter Ma Zhen 馬㮹 (1254-?) acknowledged the experience of commoners in his poetry ironically noting that "old farmers who live far away in the village pass regularly through alleys of mulberry trees and sugarcane. And still, their sons and grandsons are called into the city where they have to listen to readings on the promotion of agriculture [quannong wen 勸農文].” ${ }^{36}$ Quannong literature was the pedagogical tool of choice. It included a conglomerate of official edicts of agronomy, sayings, terminological clarifications, poetry and illustrations (often a simplified form of imperially commissioned Tilling and Weaving) with agricultural contents, along with either useful quotations from or summaries of elite and state agronomy literature, which represented what Francesca Bray has called the "science of the state." ${ }^{37}$ Ma here implies that authors such as Wang Zhen had not only their peers in mind, but truly may have expected that their elaborations would be read out loud to farmers and practitioners. ${ }^{38}$

Documents excavated in Heishui 黑水, a postal relay station located in the Hexi-Gansu corridor in Northern China, show that by 1300 imperial information campaigns had reached far into the Yuan imperial territory and to the edges of traditional sericulture regions. Local officials there also reported that they had "supervised agriand moriculture based on diverse texts." ${ }^{39}$ One of these descriptive reports by local officials meticulously lays out measurements for a mulberry plantation because, as its author had realized, the scarcity of water in the region required farmers to introduce important technical adaptations at the locality. Mulberry bushes rather than trees "should be planted every two feet in rows of ten feet ... partitioned into 60 ... with

\footnotetext{
${ }^{34}$ Newly added was cotton, Nongsang jiyao, “Mu mian” 木綿 2.31a-32a. “Si can” 44a was mostly drawn from the Shinong biyong, but information on the nurturing chamber is identified as a quote from an unknown source called “Chen Hong zhi” 陳宏志. Together with all unmarked passages, about one third of the content in the Compendium cannot be found in other literature. Newly added or unmarked passages by comparison offer insights into "Non-Chinese" fields of agricultural engagement important to new rulers mainly in the horse husbandry section. For an in-depth analysis of the language of these works see Zeng Lingxiang 曾令香, Yuandai nongshu nongye cihui yanjiu 元代农书农业词汇研究 (PhD thesis, Shandong shifan daxue, 2012), 187-89.

${ }^{35}$ For example: “移樹無時 莫教樹知 多留宿士 記取南枝” and “十耕蘿葍九耕麻.” See Lu Mingshan 魯明善, Nongsang yishi cuoyao 農桑衣食撮要 (Ming keben 明刻本 [Ming dynasty print], n.d.), “Zheng yue” 正月 9a, 10b.

${ }^{36} \mathrm{Ma}$ Zhen 馬臻, “Xiawai shiji” 霞外詩集, in Yuanren ji shi zhong 元人集十種 [1638; repr. in Jiguge Yuanren ji ji lidai shijia 汲古閣元人集及歷代詩家] Beijing: Quanguo tushuguan wenxian suowei fuzhi zhongxin, 2008), 8.11b/12a.

${ }^{37}$ Francesca Bray, Technology, Gender and History in Imperial China: Great Transformations Reconsidered (New York: Routledge, 2013), 242-44.

${ }^{38} \mathrm{~A}$ recently rediscovered stele roots Wang Zhen's life firmly within Yuan traditions and situates him geographically in Tai'an 泰安 instead of Dongping 東平. See Zhou Ying 周趴, “Wang Zhen jiqi Nongshu shizheng er ti” 王禎及其‘農書’史證二題, in Shumu wenxian 書目文獻 (published April 09, 2019; last accessed October 09, 2019, https://mp.weixin.qq.com/s/uxvJubNAWcPhZEuWtFdxVw). For the relation between agricultural themes in poetry, reading, and official state literature see also He Fasu 何发廷, “Jiangxi gengdu wenhua yanjiu” 江西耕讀文化研究, Nongye kaogu 2015.1, 293-300.

${ }^{39}$ Heicheng chutu wenshu (Hanwen wenshu juan) 黑城出土文書 (漢文文書卷), edited by Li Yiyou 李逸友 (Beijing: Kexue chubanshe, 1991), [F116:W551] 102.
} 
pathways one foot wide, sufficient for one man to walk between the rows." Intercropping (qutian 區田) with grains is promoted, a method also described by Wang Zhen, ${ }^{40}$ and the local official underlined the usefulness of his renderings by suggesting "printing multiple copies for all provinces to disseminate such information widely."

Heishui would be swallowed by the desert by 1350, but its records from the turn of the fourteenth century show a rich information flow in which the central state collected and disseminated information from literature and different regions and local officials learnt from practice and local farmers and documented such information for further use in other regions or dissemination to the central state. In this context, Yu Xilu depicts Zhenjiang through its local gazetteer as a place that embodied the success of the policies of Qubilai Khan and those of his grandson Temür Khan (ruled 12941307), in reviving Zhenjiang's former role as a hub of social life, a marketplace, and a major center for the collection of taxes. ${ }^{42} \mathrm{Yu}$ makes sure to verify that mulberry could grow in Zhenjiang, by quoting a Tang dynastic historical source; he specifies field sizes, and the amount of textiles taxes in chapter 5 on “taxes" (fushui 賦稅). ${ }^{43}$ And he adds a phenomenological description of the plant in the chapter on "local products" (tuchan 土產) explaining that different kinds of plants could feed the worms: "Zhe: of the sang-kind with small and thick leaves can also be fed to silkworms." 44

Stylistically, Yu's short, descriptive entry mirrors dictionary entries or those that can be found in materia medica (Bencao 本草), both literary styles that display Yu's erudition. ${ }^{45}$ When contextualized with further information given in the local gazetteer itself,

\footnotetext{
${ }^{40}$ See Wang Zhen 王禎. Donglu Wang shi “Nongshu” yizhu 東魯王氏“農書譯注, commented by Miao Qiyu 繆啟愉 (Shanghai: Shanghai guji, 1994), “Nongqi tupu ji zhi yi: tianzhimen: qutian” 農器圖譜集之一: 田制門: 區田, 210-12.

41 “各路镂板, 多廣印散.” Wang Zhen, Donglu Wang shi “Nongshu” yizhu, commented by Miao Qiyu, 220.

${ }^{42}$ Zhenjiang's importance as a hub by the Song is also verified by the official Qin Jiushao 秦九韶 (120261) whose mathematical guide to algebraic and indeterminate equations, geometry, and linear systems contains several references to Zhenjiang. Ulrich Libbrecht, Chinese Mathematics in the Thirteenth Century: the Shu-shu chiu-chang of Ch'in Chiu-shao (New York: Dover, 2005). For Zhenjiang's multicultural community see Dietmar W. Winkler and Li Tang, Hidden Treasures and Intercultural Encounters: Studies on East Syriac Christianity in China and Central Asia (Berlin: Lit. Verlag, 2009). For a description of the port of Zhenjiang in the nineteenth century, see Keith Stevens, "The Yangzi Port of Zhenjiang down the Centuries: 鎮江: part I," Journal of the Hong Kong Branch of the Royal Asiatic Society 42 (2002), 255-321.

${ }^{43} \mathrm{Yu}$ Xilu includes a historical reference about a plantation of mulberries trees on a tomb site during the Wei Dynasty (440). The rather large number of different textiles listed in the tax chapter reflects the fact that Zhenjiang hosted a weaving and dyeing bureau (zhiran ju 織染局) producing silk for the court and tribute. As Zhenjiang was a port city, raw silk may well have been transported there from other regions. Many of the state-owned weaving sites were located in the north. Later Ming local gazetteers of the south such as Hangzhou or Suzhou commemorate Yuan origins. In comparison, almost all northern local gazetteers avoid mentioning Yuan origins.

${ }^{44} \mathrm{Yu}$ Xilu, Zhishun Zhenjiang zhi, “Tuchan” 土產 4.35a/b: “柘 類桑 葉小而厚 亦可以飼䗟.”

${ }^{45}$ In its most basic form this reference mirrors the Erya 爾雅 (Coming close to correctness). The descriptive style follows writings such as the contemporary Tangye bencao 湯液本草 (1238-48) compiled during the Yuan dynasty. Wang Haogu 王好古, Tangye bencao 湯液本草 (Qing Guangxu keben 清光緒刻本 [Qing dynasty Guangxu edition], n.d.; repr. in Gujin yitong zhengmai quanshu 古今醫統正脈全書. Taibei: Yiwen yinshuguan, 1967), see e.g. “Mu bu: Sang bai pi” 木部: 桑白皮 3.26a/b. For the most part, Materia Medica are officially commissioned works by the Tang-Song periods. For Materia Medica styles see George Métailié, "Concepts of Nature in Traditional Chinese Materia Medica and Botany (Sixteenth to Seventeenth century)," in Concepts of Nature: A Chinese-European Cross-Cultural
} 
Yu's entry in the 'local products' chapter can be understood as a way to equip tax officers with important information necessary to perform their duty. Identifying the tree had become a crucial skill for tax officers, because by 1332 the wet regions south of the Yangtze increasingly changed from monoculture featuring plantations or orchards, originally introduced in the Song dynasty, to new cultivations with a mixed cropping method in which mulberries were grown on dikes and along fishponds. ${ }^{46}$ Tax officials could rely on straightforward measurements for field plantations (tianmu 田畧), but mixed cropping required tax officers to distinguish different kinds of tree. Field and tree counts were converted into workday calculations based on a system known already by the Tang era. ${ }^{47}$ Tax quotas were then set in the form of lengths of fabrics (so-called silk tax, shui juan 稅絹). The amount of tax-silk in Zhenjiang's local gazetteer suggests that by 1332 , Zhenjiang was successfully cultivating mulberry for the production of raw silk. ${ }^{48}$

Yu's presentation of contents underlines the purpose of Zhenjiang's local gazetteer as a handbook for local administration-for himself and for his peers. To facilitate tax recording, he sourced information (such as tax numbers) locally, and arranged it to fit the court's agenda. This is evident in the local gazetteer's categories of "local products" and "taxes." He used the gazetteer to put Zhenjiang on the Yuan moriculture map and arranged information so that later generations would have it at hand "for future use." ${ }^{49}$ In full text search of digitized texts it is easy to find similar entries about

Perspective, edited by Hans-Ullrich Vogel, Günter Dux, and Mark Elvin (Leiden: Brill, 2010), 345-67, 350. For erudite culture in Zhenjiang see Chen Lijian, "Zhishun Zhenjiang zhi suo zai Zhenjiang Dishisi," 59-62.

${ }^{46}$ For a description of the "fishpond" method, also called mulberry-dyke-fishpond method, see Kenneth Ruddle and Zhong Gongfu, Integrated Agriculture-Aquaculture in South China: The Dike-Pond System of the Zhujiang Delta (Cambridge: Cambridge University Press 1988).

${ }^{47}$ Such tax methods were widely used by the Tang and adapted by the Liao, Song, and Jin. See Wu Shuguo 吳樹國, “Shilun Jindai de sangshui” 試論金代的桑稅, Heilongjiang minzu congkan 2 (2006), 72-76 and “Songdai sangshui kaolun” 宋代桑稅考論, Shixue yuekan 11 (2006), 31-35. Möngke Khan (ruled 1251-59) had the tax form originally imposed when conquering the Jin territory. But it was mainly implemented in the south. Richard von Glahn, "Cycles of Silver in Chinese Monetary History," in The Economy of Lower Yangzi Delta in Late Imperial China: Connecting Money, Markets, and Institutions, edited by Billy K. L. So (London: Routledge, 2013), 55. The Song used a standardized quota system: “計地栽桑 計桑科絹 府州縣具有定額.” See Wu Shuguo 吳樹國, Tang Song zhiji tianshui zhidu bianqian yanjiu 唐宋之際田稅制度變遷研究 (Ha'erbin: Heilongjiang daxue chubanshe, 2007), 80.

${ }^{48}$ Because Zhenjiang hosted a local weaving and dyeing bureau, it delivered most of its taxes as finished cloth, although some raw silk was also collected: “絲八千四百四十七斤二十五兩九錢二分三嶅." Yu Xilu, Zhishun Zhenjiang zhi, “Fu shui” 賦稅 6.2a. A couple of different taxes, not only for moriculture, had to be delivered in the form of silk-juan 絲捐 (sometimes by advance-indebting [hemai 和買], as Yu also singles out). Hence the numbers alone in local gazetteers do not allow any conclusions to be drawn on mulberry taxes. Yu Xilu, Zhishun Zhenjiang zhi, "Fu shui" 6.1a-8b. The Yuan levied higher silk taxes than the Song and later Ming, yet more so in the north. The trend of Zhenjiang's juan-silk taxes is reverse: the Yuan only levied half as much as Song taxes. Fan Jinmin 范金民, "Yuandai Jiangnan sichouye shulun" 元 代江南絲綢業述論, Nanjing daxue xuebao 1992.4, 43-49. See also Fan Jinmin, Yibei tianxia: Ming Qing Jiangnan sichoushi yanjiu 衣被天下: 明清江南絲綢史研究 (Nanjing: Jiangsu renmin chubanshe, 2016), 35-37.

${ }^{49}$ The History of the Yuan mentions two tax collection forms: (1) a raw silk tax (na si 納絲), (2) granting imperial descendants and nobilities producing households, in units of five households ( $w u h u$ si 五戶絲), directly on an annual (sui ci 歲賜) basis. In the latter case, it stipulated how many lengths (in bolts, down to chi 尺 and fen 分) of silk each household transferred to which prince or princess from which place. See Song Lian, Yuan shi, 93.2361-63. Only local gazetteers record and specify the woven fabric. 
juan taxes in other local gazetteers which may seem to imply moriculture activity, ${ }^{50}$ but in fact only the mention of juan-taxes and sang tree kinds as tax category proves that moriculture was taking place, because, first, juan-tax silk was also traded across regions (to be then paid as tax) and, second, other taxes were levied in the form of juan-tax silk.

It is here that the Local Gazetteer Research Tool (LoGaRT), introduced in greater detail in the section on utilities in this issue, proves most useful. Using LoGaRT to search for keywords as they appear under specific subject-headings or editorial sections such as "local products" or within certain text structures of local gazetteers allows researchers to see when editors had similar purposes in mind-such as Yu's efforts to enable local tax collection. It is not enough to find whether terms are mentioned, what is crucial is where they are mentioned and in what context-that is, what else is mentioned around them. For the purposes of our analysis, we refer to the textual organization of different sections and the organization of content in them as the syntax. We began by combining searches of multiple terms, each in conjunction with syntactical characteristics (such as "sang" being mentioned in a "local products" section) with the aim of finding interesting cases for further research on the basis of similarities in syntax and knowledge organization. In our set of earlier local gazetteers, only the Jiading-era Zhenjiang gazetteer, which $\mathrm{Yu}$ had consulted, uses a similar strategy in its tax and local product sections, showing that in such efforts Yuan actors indeed relied locally on Song precedents. Yet, as we will see later on, Yu substantially changes the tenor and contents of other chapters, even when he sometimes continues using standard headings, which suggests that $\mathrm{Yu}$ made deliberate choices of content placement (which, although this cannot be discussed here, also appear in late Ming and Qing local gazetteers of the North and in border regions). In the still-existing twenty-four local gazetteers of the Yuan era, Yu points the way forward, as did many of his contemporaries. It must be taken into consideration that all extant local gazetteers of this period are southern examples, which means they were compiled by Song literati-or their descendants-who are known to have proliferated the genre, but who also, rather than following guidelines, enjoyed setting up alternative, even peculiar rules in their content arrangement. An issue for future research is to clarify the survival of just these two dozen rather idiosyncratic Yuan gazetteers and what their role was for the compilation of later, Ming and Qing, gazetteer compilations. ${ }^{51}$ As for those still extant Yuan gazetteers we can see that many mention juan-tax silk without mentioning mulberry trees. From this viewpoint, mentions in the tax and local product chapters alone

\footnotetext{
${ }^{50}$ Sun Shifang 孫世芳, Xuanfu zhenzhi 宣府镇志 ([China]: [publisher not identified], 1567), “Gongfu kao” 貢賦考 14.81b, for instance, notes a straight juan-silk tax (zheng shui pi bo 正稅匹帛), but no sang, reflecting that the Jin in Xuanfu raised only a conversion tax and not a moriculture tax. For the varying regional approaches to moriculture taxes (paid as juan silk) from the Song to the Jin dynasty and their reflection in local gazetteers, see Wu Shuguo 吳樹國, “Shilun Jindai de sangshui” 試論金代的桑稅, Heilongjiang minzu congkan 2006.2, 74. For the Ming era, Fan Jinmin takes the sum of juan-silk or bolts bo 帛 given in local gazetteers as evidence for moriculture. Fan Jinmin, Yibei tianxia, 17.

${ }^{51}$ No catalogues of Yuan book collectors survived. Ming collections such as the famous Tian yige 天一閣 library or the bibliophile Qi Chenghan collect mainly Ming gazetteers. Ding Bing 丁丙 lists the Zhenjiang zhi too, see Ding Bing 丁丙, Shanben shushi cangshu zhi 善本 書室藏書志 (1901; repr. in Song Yuan Ming Qing shumu tiba congkan 宋元明清書目題跋 叢刊. Beijing: Zhonghua shuju, 2006), “Shibu” 史部 11.14b. Several other copies made it into libraries in Japan and France. None of these titles appears in the "Yiwenzhi" of the database Zhongguo fangzhi ku 中國方志庫 or the Zhongguo lidai dianji zongmu 中國歷代典籍總目. Further research is also needed on later Ming and Qing gazetteers, especially in border regions that describe mulberry in similar ways.
} 
are not sufficient to assess the performance of moriculture-not even for the limited regions covered by the still extant Yuan Local Gazetters.

\section{Literary Analysis with an Empirical Orientation}

While historians are perfectly comfortable sliding between (entirely valid) exegetical claims based on just a few passages in a source (such as that sang=tree, but sang in a chapter on tax should refer to tax) and larger historical claims (such as the Yuan had more frequent disasters than other dynasties, or most local gazetteers contain chapters on local products), they hesitate when testing qualitative assessments empirically over large corpora. This reluctance has to do with the complexities and variations in the transmission of texts over time, with the suspicion that large datasets ignore editorial selections, with knowledge that that the authors of our sources chose different rules of compilation (for instance Yu Xilu's use of the prior Song edition of Zhenjiang's gazetteer as a template), and with a sense that such texts did not exist in a vacuum.

Central to our methodological concern about DH methods, the texts subsumed as local gazetteers can be understood as a compound, interlaced set of databases: we find varied, partly compatible structural designs with similar, but not always, overlapping datasets. The gazetteer of Dongming, located in Hebei in northern China, featured disasters and local weather conditions under the section heading "auspicious and ominous events" (xiangyi 祥異) in 1523, similar to the local gazetteer of the southern prefecture of Zhenjiang that had been compiled almost two centuries earlier. ${ }^{52}$ But the syntax in the two local gazetteers is very different: the fourteenth-century local gazetteer of Zhenjiang categorized different topics (distinguishing, for example, between auspicious events and strange occurrences) under which disasters are listed in chronological order. Dongming and the majority of later local gazetteers simply chronicle disasters. We built the LoGaRT platform in order to address a specific phenomenon of syntactical patterns in our analysis, to examine how its pattern of occurences can be explained in relation to the genre and thus what Dorgeloh and Wanner define as the "genre effects of syntax." 53 This approach allows us to inquire into the dialectics ("between" rather than against!) of historical meaning-making and meaning-giving indicators in local gazetteers-how topics and categories and classifications developed and which contents were featured under them. To do this we built tools to transfer textual structures into tabular structures for the currently available set of 3,999 digitized local gazetteers. LoGaRT allows researchers to run a search based on content structure (section titles) with or without syntactical anchors (keywords) to identify datasets. Then, after close reading, texts can be tagged to encode meaning and to attribute scholarly assessments and interpretations to words or text passages; this helps researchers to assess not only whether the set of all occurrences of the term "mulberry" under the category "local products" has meaning, but also how, under a certain heading, contents, in particular orders in listings (which might express certain preferences, for instance priority) and

\footnotetext{
${ }^{52}$ Chu Yuansheng 儲元升, Qianlong Dongming xian zhi 乾隆東明縣志 (1924 [1756]; repr. in Zhongguo fangzhi congshu 中國方志叢書. Taibei: Chengwen chubanshe, 1976), “Nianji xiangyi” 年紀祥異, 7.2a14b; Yu Xilu, Zhishun Zhenjiang zhi, “Xiangyi” 祥異 20.1b-3b. The port of Zhenjiang held the status of a superior prefecture ( $f u$ 府) until 1276 and then became the seat of the much larger unit of a circuit (lu 路).

${ }^{53}$ Heidrun Dorgeloh and Anja Wanner, "Introduction," in Syntactic Variation and Genre, edited by Heidrun Dorgeloh and Anja Wanner (Berlin: de Gruyter Mouton, 2011), 4.
} 
other structures of narration, might change. Tagging also makes it possible for us to follow similar contents or arrangements of contents through the genre, and eventually to track observations such as the relation between contents and headings or how headings change but contents remain largely the same. For instance, at some point disasters are listed mainly under the rubric of "strange events", but they can also appear in a locality's history or irrigation sections. By encoding these qualitative assessments into quantitative structures, historians are able to see how authors developed and used local gazetteers regionally, or how categories, arrangements of content or functions developed locally, nationally, or across different periods. ${ }^{54}$ The advantages of LoGaRT are that it allows the entire corpus (1) to be examined by a textual/syntactical search complemented with structural search (section headings), (2) to have an overview with a statistical visualization that discloses "the spatial and temporal patterns of transmission flows," 55 (3) to enable scholars to call up individual cases for checking and comparison through close reading, and (4) to implement tagging, which helps convert qualitative scholarly assessment into quantitative structures.

In the case of Big Data analysis, LoGaRT offers tools helping researchers to keep in mind what is not known, such as the limitations of the source base-what one might call the blank spots. A major task of curating data is to review prior research on the source situation. In the case of local gazetteers, the geographical range of the still extant Yuan era local gazetteers is small, but it is important to understand that during the Song, Liao, Jin, and Yuan eras, local gazetteers were mainly produced in the central Southern regions. Jiangxi, Jiangsu, Fujian, and Hunan were particularly enthusiastic about compiling local gazetteers. During the Song, major gazetteers came from Zhejiang, Sichuan, Jiangxi, Jiangsu, and Guangdong, while the Yuan added major local gazetteers in Shanxi and Shaanxi, Hebei, and Henan (Figure 1). ${ }^{56}$ Mapping the geographic coverage of the text corpus helps us to make qualitative assessments and to understand the baseline distribution of our data. It helps to interpret the blank spaces on the map, representing a textual absence. This absence of textual documentation might lead some to suppose an absence of taxes or disaster, especially when working with big textual databases, whereas it may simply indicate that a certain place had no local gazetteer, that an edition was lost, or that none is available in the digitized corpus, or data is hidden by the gazetteer's compilation rules.

Research began by curating data from varied digital and analog sources. This curation generated many insights about the genre of local gazetteers and its development, and required us to question current assumptions that cannot all be addressed in the scope of this article but are reflected in our maps and datasets. For example, we addressed issues such as how many Yuan local gazetteers actually existed, but also more difficult ones including why and how authors, from the Song to the Yuan applied,

\footnotetext{
${ }^{54}$ Shih-Pei Chen, Calvin Yeh, and Sean Wang, "LoGaRT: Local Gazetteers Research Tools," Max Planck Institute for the History of Science, accessed February 15, 2020, www.mpiwg-berlin.mpg.de/research/pro jects/logart-local-gazetteers-research-tools. Shih-Pei Chen, Dagmar Schäfer, and Qun Che, "Local Gazetteers Working Group," Max Planck Institute for the History of Science, accessed February 15, 2020, www.mpiwg-berlin.mpg.de/research/projects/departmentSchaefer_SPC_MS_LocalGazetteers.

${ }^{55}$ For an approach to visualizing epidemics in Big Data see Mei-po Kwan, “Algorithmic Geographies: Big Data, Algorythmic Uncertainty, and the Production of Geographic Knowledge," in Geographies of Mobility: Recent Advances in Theory and Method, edited by Mei-Po Kwan and Tim Schwanen (Abingdon: Routledge 2018), 176.

${ }^{56}$ If we only look at Zhongguo gufangzhi kao 中國古方志考, edited by Zhang Guogan 张國洤 (Beijing: Zhonghua shuju, 1962) for pre-Yuan local gazetteers, Zhejiang has the most (180). In this case we need to include Sichuan and Guangdong as well as Jiangxi, Jiangsu, Fujian, and Hunan.
} 


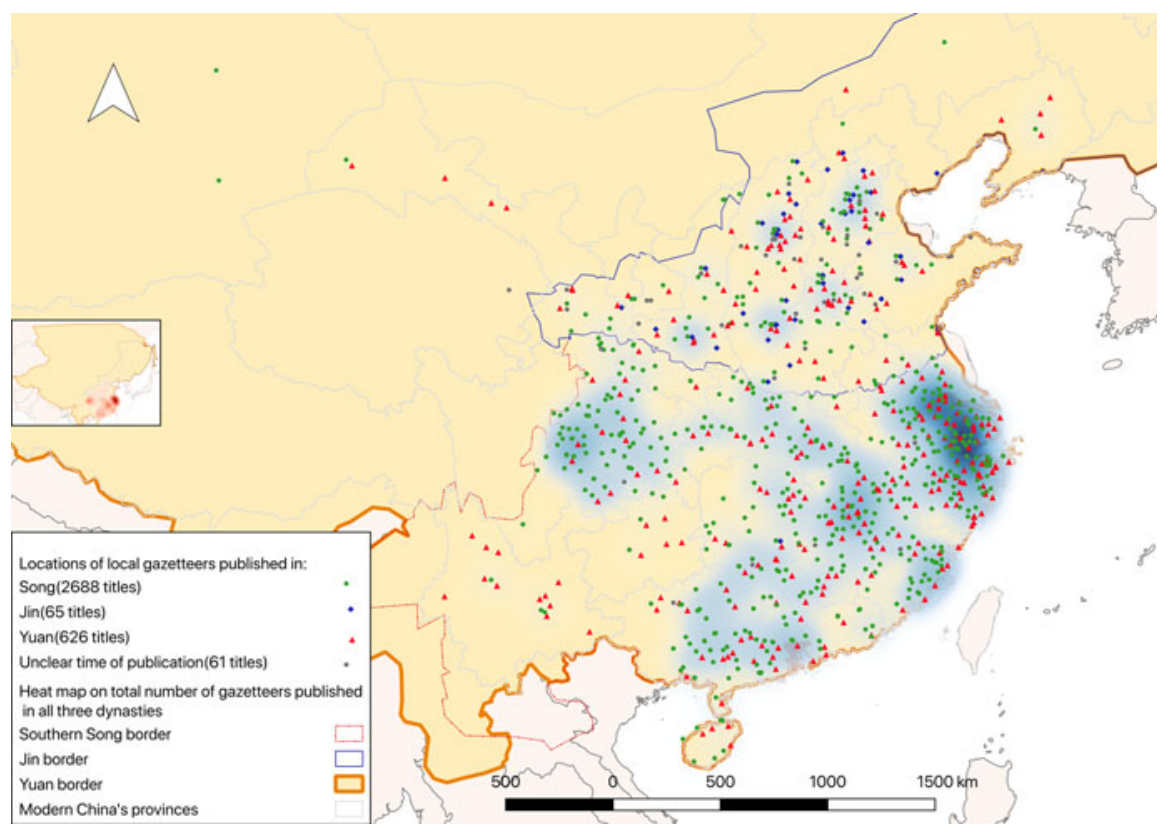

Figure 1. Geographical Distribution of Local Gazetteers Compiled or Published During the Song, Jin, and Yuan Dynasties, Both Extant and Lost. The data are drawn from four sources: Zhongguo Gu Fangzhi Kao, Song Liao Jin Yuan Fangzhi Ji Yi, Song Chao Fangzhi Kao, and Jin Yuan Fangzhi Kao. While the dots represent the coverage of locations of these gazetteers, the background heat map reflects the number of gazetteers compiled for each locale during all three dynasties. Data curation by Cathleen Paethe, Lin Nungyao, Tang Yuting, and Jiang Yexin; map by Lin Nungyao.

continued or changed the structural design of their gazetteers, and how such choices reflect social and intellectual networks. How editorial rules-and thus categorieswent in and out of fashion regionally, while the contents may have remained the same, is relevant for our understanding of local gazetteers as a source. Our mappings are also meant to highlight the limitations of our sources: while the central government issued policies to collect data across the empire in a systematic fashion and during the Yuan nearly 300 titles were compiled-some probably based on Song precedents, we do not know their actual contents and arrangements. ${ }^{57}$ The forty-two extant Song-Yuan local gazetteers vary considerably in their syntactical choices and thus the comparability of contents, with a dozen featuring, for example, mainly images ( $t u$ 圖) (Dongxiao tuzhi 洞霄圖志), biographies (Jing xiang lu 敬鄉錄) or anecdotes (Gu Hang zaji 古杭雜記). ${ }^{58}$ The various biases in these datasets have to be considered.

\footnotetext{
${ }^{57}$ The Da Yuan da yitong zhi 大元大一統志 was ordered in 1285. Edited by Zhamaluding 札马刺丁 and expanded by Bolanxi 孛蘭肹. The current edition is incomplete and was recompiled based on the Yongle dadian 永樂大典. See also Zhang Guangda's Qiuhuang huomin leiyao who summarized relief measures from various historical tracts. Zhang Guangda 張光大, Jiuhuang huomin leiyao 救荒活民類要 [1321; Ming keben明刻本 [Ming dynasty print] n.d.; repr. in Xuxiu Siku quanshu 續修四庫全書] Shanghai: Shanghai guji chubanshe, 2002), 1-82.

${ }^{58}$ These numbers result from consultation of Song Yuan fangzhi congkan 宋元方志叢刊 (Beijing: Zhonghua shuju, 1990), Song Yuan zhenxi difangzhi congkan 宋元珍稀地方志叢刊 (Chengdu: Sichuan daxue chubanshe, 2007), Yuandai shiliao congkan chubian: Yuandai dili fangzhi 元代史料叢刊初編: 元
} 
Because structural features can be addressed in LoGaRT, this offers an exciting avenue for inquiring into the genre itself. Automated analysis can conveniently compare regional differences in structure and content that would require an unimaginably huge investment of time and energy when done by analog reading. In automated queries, exceptions to the rule stand out and can be used to detect and fix the bias contained in one's method and analysis or to identify interesting deviations from an assumed norm. Skimming large sets of data, we can detect interesting exceptions that have been overlooked by research (such as singular examples of disaster records from one specific border region). Or assumptions that have been inferred about larger sets by relying on particular examples (such as about the content organization of southern, Jiangnan, etc. local gazetteers) can be tested. Historians, seeing Yuan local gazetteers sandwiched between the Song and Ming, have focused on their structural continuity with Song gazetteers and the improvement of their Ming successors. Huang Yansheng, for instance, notes that the "majority" of Yuan local gazetteers still showed a continued interest in taxes and in household numbers. He sees Yuan gazetteer editors as increasingly standardizing the use of images and applying an encyclopedic approach to collecting local knowledge. He suggests that Yu Xilu modelled the Zhenjiang local gazetteer on the Song-dynastic Jiading "bureaucratic" gazetteer while Yu was particularly meticulous in his "scrutiny of economic goods." Although it is not surprising that the Song and Yuan editions are similar, it can be quickly shown using LoGaRT that no other extant Song-Yuan local gazetteer replicates this content-structural pattern. ${ }^{60}$

Close reading, combined with an empirical orientation, can reveal significant insights into both the idiosyncratic case and the development of the genre itself. Instead of “people" (renwu 人物) Yu, for instance, chose "human talents" (rencai 人材) to title a listed recording of professions such as archers, doctors, or monks, and ethnic-linguistic groups (such as Huihui, Hexi, Qidan, Han), thus reflecting an era and dynasty that recruited groups other than literati-scholars into its state apparatus, assembled practical talents at the court and traded talented craftsmen and experts as slaves across long distances. ${ }^{61} \mathrm{He}$ has a section on “buildings" (gongshi 宮室) that includes information on the broad range of other religious and cultural buildings in Zhenjiang reflecting the cosmopolitan, multicultural, and multi-religious character of Yuan rule. ${ }^{62}$ Early Big Data research tended to collapse differences, but tagging can

代地理方志 (Anhui: Huangshan shushe, 2012), Song Yuan dili shiliao huibian 宋元地理史料匯編 (Sichuan: Sichuan daxue chubanshe, 2007), and Song Liao Jin Yuan fangzhi jiyi 宋遼金元方志輯佚 (Shanghai: Shanghai guji chubanshe, 2011). They list 179 local gazetteers of the Yuan. Zhongguo gufangzhi $k a o$ accounted for 160 Yuan local gazetteers. Jun Fang identifies 210 without revealing his source. He then lists 31 extant local gazetteers. Jun Fang, "A Bibliography of Extant Yuan Gazetteers," Journal of Song-Yuan Studies 23 (1993), 123-38.

${ }^{59}$ Huang Yansheng 黄燕生, “Yuandai de difangzhi” 元代的地方志, Shixueshi yanjiu 1987.3, 38-48 also notes that Yuan local gazetteers equally aimed at comprehensive coverage and this era's authors already engaged with enthusiasm into historical accounts.

${ }^{60}$ The Yuan local gazetteer of Jiahe lists several kinds of mulberries. Xu Shuo 徐碩, Zhiyuan Jianhe zhi 至元嘉禾志 (1839; repr. in Song Yuan fangzhi congkan. Beijing: Zhonghua shuju, 1990), and offers taxes, "Wuchan" 物產 6.3b-6a. As the number is small, we cross-checked the automated result additionally one-by-one.

${ }^{61}$ See Thomas Allsen, Culture and Conquest in Mongol Eurasia (Cambridge: Cambridge University Press, 2010), 201.

${ }^{62}$ The section is followed by a section on "government buildings" (gongxie 公廨). Yu Xilu, Zhishun Zhenjiang zhi, “Mulu” 目錄 $2 \mathrm{~b}$. 


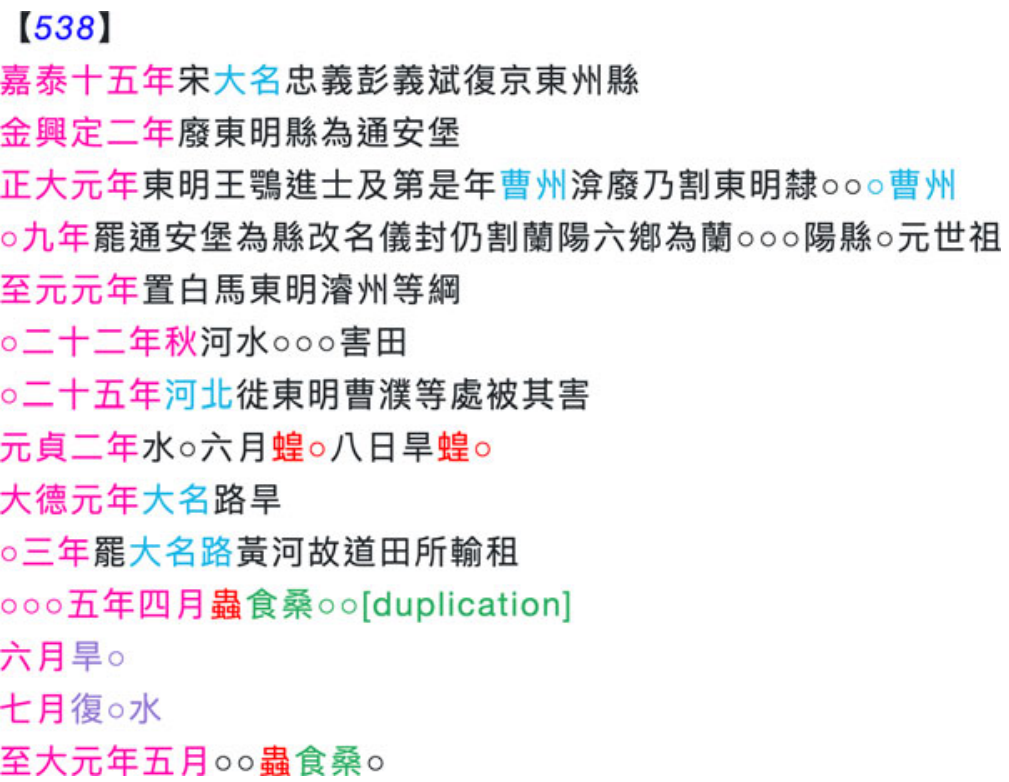

Figure 2. Tagging as a Curation Process. This figure shows LoGaRT's tagging interface with a text snippet from the 1756 Dongming Xian Gazetteer, resulted from keyword search for mulberry disasters. We tagged the dates of when such disasters happened, place names, reasons, and results of mulberry loss, all shown in different colors. LoGaRT allows scholars to define thematic topics for tagging and tags, then assign tags to parts of text to specify their meaning, and also incorporate their assessments of the text parts.

address such issues, as historians can decide which word groups they wish to form and which expressions within a specific search should be deemed duplications, typos or similar or which ones carry meaning (Figure 2). The collation of data across large sets of texts in LoGaRT has another advantage. It allows us to see content nuances in relation to changing structural emphasis given by the gazetteer's syntax. Yu Xilu, for instance, added a subsection on "auspicious and inauspicious events," which the Song edition did not have. Yu located this subsection in the final chapter on "miscellanea" (zalu 雜錄). ${ }^{63}$

The heading of "auspicious and inauspicious events" invokes a standard rubric of imperial historiography (zhengshi 正史) which, as local historians regularly emphasize, had been in use since Han times. ${ }^{64}$ A search in LoGaRTs repositories shows, however, that Song and Yuan local gazetteers rarely use "auspicious and inauspicious events" as a heading, even if they document such events. Also, the content of this category varied considerably. Wuzhou's Yuan local gazetteer offered locally flavored "tales of the strange" under this rubric, thus emulating Tang approaches and earlier views of what made the local interesting. $\mathrm{Yu}$, though, under this rubric "orders the past for future

\footnotetext{
${ }^{63} \mathrm{Yu}$ Xilu, Zhishun Zhenjiang zhi, "Mulu” 目錄 3 b.

${ }^{64}$ Even though local studies emphasize that such a section can be found already in earliest imperial Han dynastic local gazetteers, only a couple of Song dynasty gazetteers actually feature such sections. Reviewing tables of contents and the small number of still extant Song gazetteers, the Zhongguo gufangzhi kao identifies a good dozen of the 810 known local gazetteers with such a chapter heading-among them four of the titles included in the set researched here.
} 
use." ${ }^{65}$ In noting the floods and gales of Zhenjiang's past, Yu Xilu provided a historical snapshot of the environmental dangers significant to the management of a port city on the Yangtze river.

Yu Xilu introduces a category of “auspicious and omnious events” (xiangyi 祥異), but stays clear of Yuan legitimacy debates. He chronicled events from the Jin 晉 through to the Tang era ${ }^{66}$ as historical references, but avoided references to incidents during the Song that could have been interpreted as political statements on "portents" and been used to support arguments about these ruling houses legitimacy. ${ }^{67}$ For the same reasons he may also have wanted to avoid references to the Yuan era. Although no conclusive statement is possible because of the few surviving editions, in those that survive $\mathrm{Yu}$ Xilu is the only editor to add a disaster section. His approach to Zhenjiang's disaster reporting prompts several questions regarding the sourcing of such data, the purpose editors had for mentioning disaster data in local gazetteers, and how such sections were developed and used throughout time. In contrast to the unique example of Zhenjiang, the Dongming local gazetteer is one of a larger group of early to mid-Ming local gazetteers that included Yuan disasters. In the case of this northern county, almost two hundred years separated the actual disaster event from its first mention in the provincial gazetteer for Daming to which Dongming was subordinated since $1490{ }^{68}$ Although Dongming became a county in 963, its first local gazetteer (now lost) dates from 1536. ${ }^{69}$ As Gao Xiang's preface to the 1536 edition explained, he had adapted existing classification schemes to fit their purpose of depicting "the everchanging vestiges that are the course and change of any development." ${ }^{\prime 70}$ Starting with a typical arrangement of data in the categories of heavenly patterns (tianwen 天文 i.e., astronomy and astrology), patterns of the earth (dili 地理, geography), affairs of government (zhengshi 政 事), and historical figures (renwu 人物), editors added rubrics for government

\footnotetext{
${ }^{65}$ Bol, "The Rise of Local History," 49.

${ }^{66} \mathrm{Yu}$ ends with the year 858 when enormous floods along the Grand Canal inundated Northern China and several thousand people drowned. Yu Xilu, Zhishun Zhenjiang zhi, “Xiangyi” 祥異 20.1b-3b.

${ }^{67}$ Wei Chongwu 魏崇武, “Lun Meng Yuan chuqi de zhengtong lun” 論蒙元初期的正統論, Shixueshi yanjiu 2007.3, 34-43.

${ }^{68}$ Contained in the Erudition dataset are two early editions of the Daming fu zhi 大名府志, one edited by Li Lu 李輅, Zhao Ben 趙本, and Wu Ji 吳驥 in 1445, and the other edited by Shi Lu 石祿 and Tang Jin 唐錦 in 1506. Before 1208 Dongming had been subordinated to Kaizhou 開州, then after 1208 to Caozhou 曹州. From after the Ming conquest in 1367 until 1377 the unit was dissolved and governed from Kaizhou, Changyuan county, before being permanently returned to Daming. The administrative changes are described in the gazetteer itself, and dynastic histories can be followed in CHGIS. Both the Kaizhou and the Changyuan gazetteers were compiled slightly before the first Dongming gazetteer in 1534, however, also clearly after that of Daming. None of them contains Yuan disasters records for Dongming. Wang Chongqing 王崇慶, (Jiajing) Kaizhou zhi (嘉靖) 開州志 (1534; repr. in Yuan Guoli Beiping tushuguan jia ku shanben congshu 原國立北平圖書館甲庫善本叢書. Beijing: Guojia tushuguan, 2016), “Xiangyi” 祥異 8.1a-7b, and Liu Fang 劉芳, (Jiajing) Changyuan zhi (嘉靖) 長垣志 (1534; repr. in Yuan Guoli Beiping tushuguan jia ku shanben congshu 原國立北平圖書館甲庫善本叢書. Beijing: Guojia tushuguan, 2016), “Zaixiang”災祥 8.55b-57a.

${ }^{69}$ See Old Preface ( jiu $x u$ 舊序) by Yang Risheng 楊日升 in Chu Yuansheng, Qianlong Dongming xian $z h i$, “Jiu xu” 舊序, 9b.

${ }^{70}$ The editors also point towards the Zuozhuan and Shiji (大抵如左氏史遷之法). Zuozhuan, which is chronological, and Shiji, which is by events, are the major two frameworks of Chinese historiography: “是志者史屬也夫志之體必天文地理政事人物世代風俗常變之迹沿革之由備書而詳紀之大抵如左氏 史遷之法故曰志.” The classification scheme was chosen arbitrarily: “遂約諸生徒立凡例定程規門分類.” See Old Preface (jiu xu 舊序) by Gao Xiang 高橡 in Qianlong Dongming xian zhi, “Jiu xu” 舊序 3a, 3b.
} 
buildings (gongyu 公宇) and shrines and sacrifices (cisi 祠祀), historic relics (guji 古 蹟), and taxes (Tianfu 田賦) “in an attempt to provide facts, to learn about disasters and auspicious events, to point out vigilance and admonishments, to extend one's knowledge about what can be seen and heard, to see the achievements and failures of administration, and to allow scrutiny of the rise and fall of customs and habits, to be passed on eternally and without any concealment."

Specific sections of a local gazetteer, such as disasters, were not only affected by local conditions, individual editorial choices, or textual transmission. In the case of Yu Xilu's gazetteer, political ideologies and intellectual trends affected disaster-reporting practices at the time, and their historical reception. By including Tang records on big floods, $\mathrm{Yu}$ during Yuan reign provided administrators with useful information about local conditions and hazards, outlined prior failures and, by remaining silent about his own times, avoided a contentious political theme. In the case of Dongming we equally need to consider how Yuan officials originally handled and documented mulberry disasters, and how Ming local gazetteer editors, local officials, or members of the local scholarly elite reflected on the Yuan and on disasters in their own time.

The Kangxi edition of 1673, the earliest extant edition that puts Dongming on the Yuan disaster map, ${ }^{72}$ followed the structure of four preceding Ming editions (1536, 1599,1612 , and 1623). The "old preface" to the 1536 edition indicates that editors consulted local sources, but in fact many northern gazetteers for which the first edition appears in the mid-Ming era based their accounts of earlier events on dynastic histories. $^{73}$ The extant Qing editions do not specify whether Dongming cultivated mulberry trees or had to pay juan-taxes in Yuan, but give field sizes for moriculture for their own eras. ${ }^{74}$ The Kangxi and Qianlong editions would add on disaster events towards the actual date of compilation while continuing to copy prior entries without adding further information from other sources on matters such as tax relief or damage reports. ${ }^{75}$ How, then, did Dongming's moriculture disaster records relate to Yuan practices and politics of disaster recording? To answer this question, we queried the current set of digitized gazetteers of 3,999 titles. $^{76}$

\footnotetext{
${ }^{71}$ See Old Preface by Gao Xiang in Qianlong Dongming xian zhi, “Jiu xu” 舊序 3 b.

${ }^{72}$ Of Daming fu zhi compiled by $\mathrm{Li} \mathrm{Lu}$, Zhao Ben, and Wu Ji in 1445. The records are still in the 1506 re-edition by Shi Lu and Tang Jin, and in the 1672 edition by Gao Huanyuan 趴煥元 and Zhou Bangbin 周 邦涁. All are available in Zhongguo fangzhi $k u$ 中國方志庫, licensed through Berlin State Library's CrossAsia and in Gugong zhenben congkan 故宮珍本叢刊, edited by Gugong bowuyuan 故宮博物院 (Haikou: Hainan, 2001). Xijian Zhongguo difangzhi huikan 稀見中國地方志彙刊, edited by Zhongguo kexueyuan tushuguan 中國科學院圖書館 (Beijing: Zhongguo shudian, 1992). For a full overview of the county's administrative changes from Song to Qing, see China Historical GIS (Harvard University and Fudan University) records of the following numbers: hvd_44368, hvd_44813, hvd_44814, and hvd_44815.

${ }^{73}$ For the emergence of northern local gazetteers, see Bai Biling 白璧玲, “Ming Qing shiqi Huabei Huang fanqu wenhua jingguan zhi xingsu yu bianqian: yi Kaifeng fu diqu wei zhu” 明清時期華北带泛區文化景 觀之形塑與變遷: 以開封府地區為主 (PhD diss., Taiwan Normal University, 2012).

${ }^{74}$ In several instances the local gazetteer notes silk related taxes, which confirms that Dongming continued sericulture. Silk from official mulberry land translated into 4 liang 兩, 5 qian 錢 silk per $m u$ 畧 of land. Moriculture fields in private hands were charged by 1 liang 兩 silk threads. Silk floss was raised per male head, amounting to 11,460 liang 兩, 553 bolts of tax silk, which is per adult male one liang and per eight liang one bolt of tax silk. By 1507 the county had to deliver 443 liang 兩 strings of silk floss and 21 bolts, 1 zhang 丈 of juan-tax silk. Chu Yuansheng, Qianlong Dongming xian zhi, “Fu shui” 賦稅 3.19a.

${ }^{75}$ In the Republican era editors increasingly aimed at updating and complementing accounts.

${ }^{76}$ This set is from Erudition's Zhongguo fangzhi ku. Another 410 titles are from Harvard Yenching Library's rare book collection. In this article we only use the Erudition set, which ranges from Tang
} 


\section{Data Curation: Mulberry-Related Disasters}

To assess Dongming's records on moriculture disasters within the whole set of gazetteers we first extracted information about mulberry disasters through a full-text search with a set of keywords that incorporated regional and historical variations in language, and next identified typos, marked them (for identification) and normalized them. ${ }^{77}$ Using semi-automated exclusion processes and close reading, data was then normalized-that is cleansed of irrelevant mentions and duplicates (same disaster at the same year/month at the same place). We found 298 reports of moriculture disasters, most of which were in sections for auspicious and ominous events or related sections titled as chronologies of events (for example, ji 紀, nianbiao 年表) and a few under relief policies (xuzheng 恤政). We then geo-coded each report in this dataset and, since some of the reports mentioned that the disasters actually took place in several counties, in this process we expanded the dataset to 404, specifying the mulberry disaster events at actual plottable locations. One hundred and fifty-six of the actual reports and 208 of the expanded geo-referenced recorded disaster events are from the Yuan. These data served as the basis of our analysis. ${ }^{78}$

Collating the data and the spatial and statistical analysis on the dataset's chronology showed several interesting patterns. As we tagged events in primary sources, we observed several patterns, such as that the nomenclature of moriculture disasters during the Yuan was particularly rich. Mapping confirmed prior observations that moriculture disasters appeared until and mostly during the Yuan dynasty (52 percent), but not so much during the Ming and Qing. ${ }^{79}$ Figure 3 shows a chronological overview of the dataset by dynasty (and reign era) of occurrence and by dynasty of appearance in local gazetteers. For example, moriculture disaster events reported in these local gazetteers reach back as early as the Western Han dynasty, yet all local gazetteers that mention moriculture disasters were published in the Ming (29), Qing (109), and the Republican (18) period. Figure 4 shows changing dynastic emphasis on moriculture disasters. Displaying Yuan data proportionally to the increase in the number of local gazetteers during the Ming, Qing, and Republican periods illustrates that Yuan data were quite consistently carried over from earlier editions, suggesting that faithful copying enhanced the impression of a peak of moriculture disasters during Yuan times.

For comparative purposes we curated another dataset of moriculture disaster reports from the "Five Phases" chapters (wuxing zhi 五行志) of the History of the Yuan (Yuan $s h i$ 元史), a Ming era compilation, and the New History of the Yuan (Xin Yuan shi 新元 史), a Qing era compilation. Ninety-seven reports were found based on a full text search of “mulberry" (sang 桑) and “silkworm” (can 蟼). ${ }^{80}$ We expanded these into location-

(618-907) through Minguo (1912-49), while the majority of gazetteers were published in the Ming (510), Qing (2,733), and Minguo (721). Currently LoGaRT links to 4,409 digitized local gazetteers.

${ }^{77}$ We collected thirteen keywords indicative of mulberry disasters which we expanded as we read through primary sources: shisang 食桑, shasang 殺桑, sangsun 桑損, sang duosun 桑多損, sunsang 損桑, haisang 害桑, huaisang 壞桑, sangguo dangjin 桑果蕩盡, feican shi 廢䗟事, sangzai 桑災, sangcan jiezai 桑䗟皆 災, sangdiao 桑调, and shangsang 傷桑.

${ }^{78}$ The data curation process involves several colleagues and student assistants, whom we would like to thank here: Cathleen Paethe, Calvin Yeh, Luo En-Mien, Zhao Wenhua, Lin Nung-yao, Liu Yuxin, Du Ruixuan, Tang Yuting, and Jiang Yexin.

${ }^{79}$ Western Jin (17\%), Northern Song (11\%), and Ming (10\%).

${ }^{80}$ This dataset is based upon the database curated by Lin Nung-yao, Hung Yi-Mei, and Su Hong-Ting for natural disasters from the twenty-five official histories (Ershiwu shi 二十五史). Substantial differences mark these sources, Song Lian's compilation of the Yuan shi sourced the Yuandai gechao shilu 元代各 
200

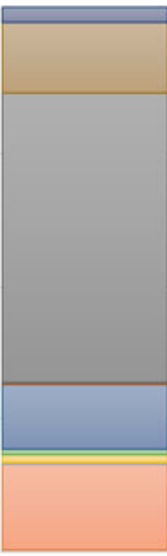

清

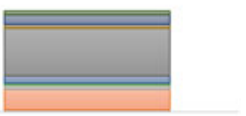

民䧆

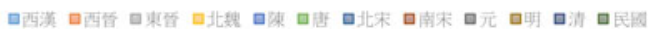

Figure 3. Chronological Breakdown of Mulberry Disasters Reported in LG: Dynasties of the Disasters and When They Were Published in LG.

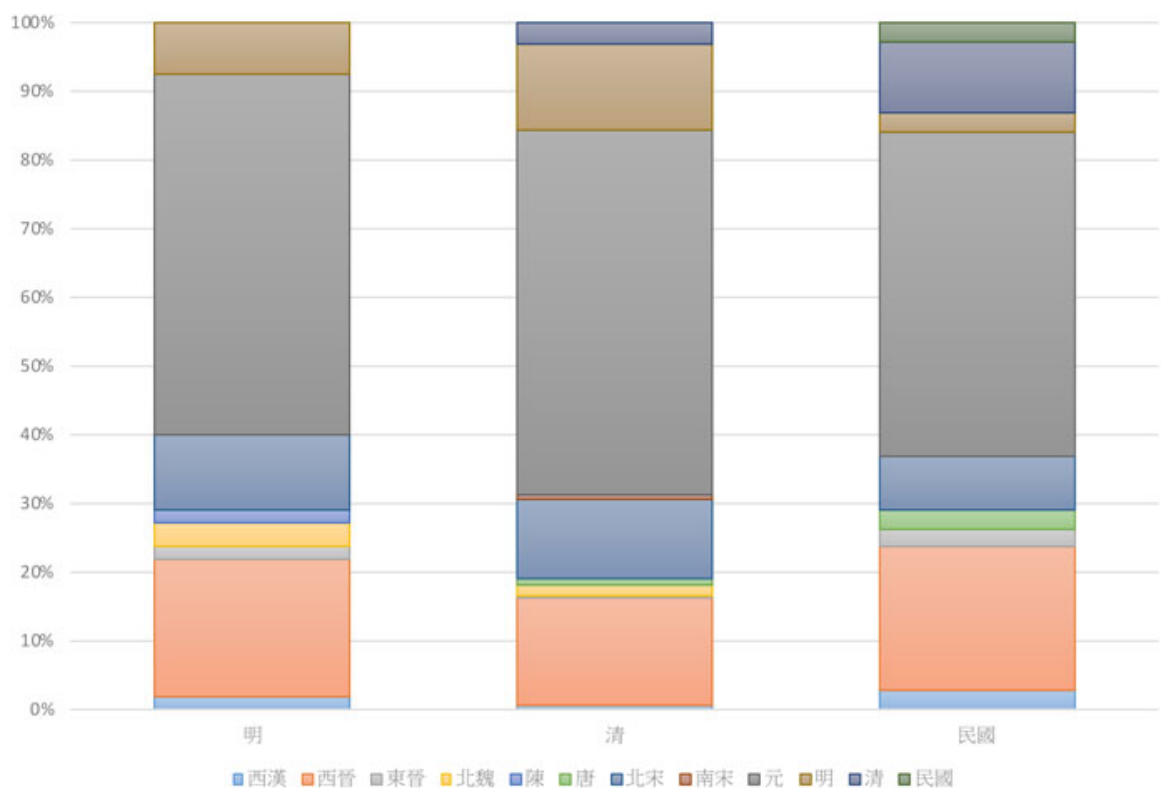

Figure 4. Chronological Breakdown of Mulberry Disasters, Proportional to Number of Extant LGs Published by Each Dynasty

朝實錄 and the Jingshi dadian 經世大典, whereas Xin Yuanshi 新元史 compiled by Ke Shaomin 柯劭莣 during the Qing also used the Yongle dadian 永樂大典, the Yuanshi yiwen zhengbu 元史譯文證補 and the Yuanshi leibian 元史類編. See Song Lian, Yuan shi, 1-4. See also Zhang Jianghua 張京華 and Huang Shuhui 黄曙輝, “Chuban shuoming” 出版說明 in Xin Yuanshi, compiled by Ke Shaomin, 1-30. 
based plottable disaster events and obtained 217 cases. The set of all disasters from Yuan dynastic histories is also preserved for baseline reference. Our first step was to ask how the data reflected practices and policies of disaster management. In a second step we compared politics of the gazetteers and Yuan data management from other dynasties.

\section{Disasters in Dongming: Yuan Bureaucracy in Ming Local Gazetteers}

Dongming was a northern county situated east of the Taihang Mountains where the Yellow river spilled into an alluvial zone of rich agricultural lands, and was, like Zhenjiang, no stranger to disasters, in particular capricious floods and droughts. Under the Song, officials from here had participated in capital politics. ${ }^{81}$ It would survive multiple military incursions during the Jin-Song wars (1125-27) and Mongol-Jin wars (1215-26). By 1301, the year of Dongming's first recorded mulberry-related disaster, however, wars had moved elsewhere. ${ }^{82}$ We can imagine farmers in Dongming working their rich alluvial fields in relative peace, growing grain and raising silkworms as they had done in this region since pre-Tang times. They would have been contributing to the Yuan's abundance of panni tartarici silk and gold textiles which we still find spread throughout the modern museum world. ${ }^{83}$ Chinese textual sources of the Yuan consistently emphasized the pressure placed on localities such as Dongming to revive silk production in the post-conquest period and increase output. A poem by Wang Yun 王惲 (12271304), a former politician and scholar of the Jin dynasty, also describes the incredible hazards of mulberry cultivation for farmers livelihoods:

Young mulberry develops green leaves by the end of spring, charmingly sparkling in the sunlight. A farm family's annual budget is indeed unstable.

Farmers' wives look after the mulberry trees, sweeping away the worms [sao sangyi 掃蛀蟻]. ${ }^{84}$

But a black frost sweeps over the land so that 10,000 trees are dried out and, encountering a torch, are burned up;

or even if they continue into the spring, their branches are sheared off by heavy winds from the sea, and the business is ruined. Though the Goddess of Weaving is appealed to, the loom is empty. ${ }^{85}$

\footnotetext{
${ }^{81}$ Dongming's population was also quite active in capital politics and during the 1071 reform campaign. See Ruth Mostern, Dividing the Realm in Order to Govern: The Spatial Organization of the Song State (9601276 CE) (Cambridge, MA: Harvard University Asia Center, 2011), 304.

${ }^{82}$ In comparison to earlier periods, as Humble notes, the dynastic biographies of this period also emphasize consolidation and adherence to rules and regulations as a major characteristic. Geoffrey Humble, "Princely Qualities and Unexpected Coherence: Rhetoric and Representation in 'Juan 117' of the 'Yuanshi'," Journal of Song-Yuan Studies 45 (2015), 317. This included the intensive promotion of agriculture including that "all possible parts of the steppe that could be put under the plow" were used. See John Dardess, "From Mongol Empire to Yuan Dynasty: Changing Forms of Imperial Rule in Mongolia and Central Asia," Monumenta Serica 30 (1972), 153.

${ }^{83}$ Jiang Ying 姜穎, Shandong sichou shi 山東絲綢史 (Jinan: Qi Lu shushe, 2013), 247-57. Juliane von Fircks, "Panni Tartarici: Splendid Cloths from the Mongol Empire in European Contexts," Orientations 47 (2014), 28-37.

${ }^{84}$ Translates as: to sweep the newly-born silkworms off the silkworm egg paper into baskets with mulberry leaves inside.

85 桑災嘆: 穉桑發暮春 緑葉光旎旎 田家嵗計固不常 農婦相桑掃罍蟻 黒霜一夜從天來 萬樹焦枯遭 燎燬 令春継以海多風 剪碎枝條生意靡 天孫仰訴錦機空, see Wang Yun 王惲, Qiujian ji 秋涧集 (1498; repr. Sibu congkan 四部叢刊, Taibei: Taiwan shangwu yinshuguan, 1979), “Sangzai tan” 桑災嘆 9.9a. For
} 
Wang spent most of his life in Hebei, Shandong, and Fujian; he identified north China as a region that had long been familiar with moriculture. He urged Yuan emperors to alleviate the farmers' burden with tax relief and compensation (which could include financial support for the raising or purchase of new seedlings) whenever disaster struck. As Chen Gaohua has pointed out, the Yuan implemented different governance practices and regimes in different regions of their empire. They favored their steppe homeland in every regard and they differentiated northern and southern regions when handling and taxing agriculture and sericulture. Variations in local farming practices and natural conditions explain regionally different approaches to tax policy and practice. This practice reached back to the Northern Song, when the government had begun introducing sericulture in the south, while relying on the established tradition of such trades in the north. Before 1260, Yuan officials mainly continued the policies of previous dynasties. In 1294 Qubilai Khan adopted Jurchen-Jin disaster policies and ideas. Emperors in 1295-1332 increasingly accepted Neo-Confucian views from the Southern Song. By the 1340s the regions had again broken apart, leading eventually to civil war. ${ }^{86}$ Tracing this trajectory it becomes clear that the Song treated north and south differently and that the Yuan enforced this trend by following Jin politics (which had adapted Song policies) in the north and Song approaches only in the south. Because the north had cultivated mulberry for a long time, Yuan rulers anticipated regular yields, as this had been the case before the conquest; the south was treated as an area of new cultivation where farmers and local officials mostly monitored new plantations. Disasters were thus regionally defined, and even if one occurred in the south, the economic effects were expected to be less severe.

In the History of the Yuan and local gazetteers, most disaster reports refer to regions whose levies were based on the five-household silk quota system. Whenever a disaster was expected to bring about a loss of more than 40 percent of the expected tax revenue a report had to be made and local taxes were reduced accordingly. ${ }^{87}$ As noted earlier, this was just the tip of the iceberg, as only severe disasters were reported by censors to the central government. As Shen Youliang notes, there was a third level in the disaster selection process: depending on the gravity of the disaster and the efficiency of relief measures, the upper level of the central government usually reacted with an inspection. ${ }^{88}$ If the authors of local gazetteers made regular use of local information, whether from personal experience, by hearsay, or by consultation of local archives-as historians

his discussion on legitimacy see Yuan Chen, "Legitimation Discourse and the Theory of the Five Elements in Imperial China," Journal of Song-Yuan Studies 44 (2014), 350.

${ }^{86}$ Chen Gaohua 陳高華, “Yuandai zaihai fasheng shi gaishu” 元代災害發生史概述, in Yuanchao shishi xinzheng 元朝史事新證, edited by Chen Gaohua 陳高華 (Gansu: Lanzhou daxue chubanshe, 2010), 5257. For Chen, taxes were the major reason for regionally different disaster approaches and he notes that Yuan approaches relied on the Song expanded surveillance of locust plagues, epidemics, and famines. For a finer regional distinction moriculture disasters and sericulture in Sichuan should also be considered, but, as in other studies, they are not included here, because the source situation is difficult.

${ }^{87} \mathrm{Da}$ Yuan shengzheng guochao dianzhang 大元聖政國朝典章 (Beijing: Zhongguo guangbo dianshi, 1998), 1020. “水旱災傷皆隨時檢覆得實 [...] 損八分以上其稅全免損七分以下止免所損分數收及六 分者 稅既全徵不須申檢.” Wang Peihua 王培華, Yuandai beifang zaihuang yu jiuji 元代北方災荒與 救濟 (Beijing: Beijing daxue chubanshe, 2010), also mentions that the loss of 10-40\% would not be reported and recorded, but that does not mean no disasters happened.

${ }^{88}$ Supervision also included the punishment of tax officials; see Shen Youliang 申友良, Xiao Yue'e 肖月 娥, “Yuandai shenjiang tifu zhidu yu jian zai jiu zai” 元代申檢體覆制度與減災救災, Zhanjiang shifan daxue xuebao 33.5 (2012), 9. 
of local gazetteers and disasters such as Luo Lin made explicit but most studies take as a default assumption ${ }^{89}$-we should find some traces of the hierarchy of such reporting practices. To assess this, we searched for different strategies, allowing for copying, duplicates, and text reuse.

\section{Hierarchies/Geographies of Reporting}

Historical sources can be interpreted in two directions: as a reaction to or as a product of certain conditions. When Shen, following other historians, ${ }^{90}$ assumes that the state's increased sophistication in policies of disaster management was a reaction to an increased disaster rate, he focuses on textual production as a reactive effort. What do these data thus allow us to say about the enactment of Yuan administrative rules on disasters and their management?

As Shen has emphasized, the Yuan code on administrative hierarchies of reporting, handling, and archiving disasters ruled that the transmission of a disaster report within the system depended on its severity - the more severe the disaster, the higher it travelled up in the administrative hierarchy of county (xian 縣), prefecture (zhou 州), superior prefecture ( $f u$ 府, assigned for strategically important places), and circuit $\left(l u\right.$ 路). ${ }^{91}$ According to various rules given in the Great Record of the Unified Yuan Dynasty (Da Yuan da yitong zhi 大元大一統志), we have also to take into account that, whereas local levels were directly responsible for handling disasters, only the central government and court could grant tax relief or even offer additional grain supplies or financial help. ${ }^{92}$ Usually local officials had to first seek help within their districts/countyfrom rich gentry, for instance-and were not allowed to request help from bodies such as the local granaries (for famine relief). ${ }^{93}$ The regional censors, in positions subordinate to the central censorate (xingyu shitai 行御史台) were the only administrators empowered to decide on tax issues, communicate with the court directly, and react on an ad hoc basis. ${ }^{94}$ Those censors strictly supervised prefectural offices (luzong guanfu

\footnotetext{
${ }^{89}$ Luo Lin, “Zhongguo gudai difangzhi zhi zaiyi jilu," 295. See Zhai Yu 翟禹, “Yuandai zaihai shi yanjiu shuping (yi)” 元代灾害史研究述评(一), Chifeng xueyuan xuebao 7 (2018), 10-15, and the second part in Chifeng xueyuan xuebao 8 (2018), 32-38; Gu Jing 顧靜, Zhao Jingbo 趙景波, and Zhou Jie 周杰, “Guanzhong diqu Yuandai ganhan zaihai yu qihou bianhua” 關中地區元代幹旱災害與氣候變化, Haixiang dizhi yu disiji dizhi 27 (2007), 111-17. For an analysis of corruption and financial incentives, but also notions of ecology and nature, or Yuan nomadic life styles and how those may have influenced the perspective on what exactly constituted a disaster, see Zhao Xinggen 赵杏根, “Yuandai shengtai sixiang yu shijian juyao” 元代生態思想與實踐舉要, Ha'erbin gongye daxue xuebao 3 (2013), 125.

${ }^{90}$ Shen refers to the 2006 Chinese translation of Alien Regimes and Border States, 907-1368, edited by Herbert Franke and Denis C. Twitchett (Cambridge: Cambridge University Press, 1994).

${ }^{91}$ Shen Youliang and Xiao Yue'e, "Yuandai shenjian tifu zhidu yu jian zai jiu zai," 106. Note also that “reported disasters” (gaozai 告災) are always “disasters under scrutiny by censors” (shenzai 申灾).

${ }^{92}$ Da Yuan shengzheng guochao dianzhang, 1019: “今後各道按察司如承各路官司申牒災傷 去處 [...]”. See also Quan Yuan wen 全元文, edited by Li Xiusheng 李修生 (Nanjing: Jiangsu guji chubanshe, 2000), 2.48.38.

${ }^{93}$ Quan Yuan wen, 26.841.474.

${ }^{94}$ Censors (fengshi 奉使, yushitai 御史臺) were not punished, whereas local officials were regularly accused of corrupt practices. See for instance Song Lian, Yuan shi, 166.3913. Therefore, individuals often used their own money, instead of asking for relief. During the great famine of 1327 in Guanshan 關陝, for instance, the official Mazha'ertai 馬札兒台 helped by spending his own funds (jinchu sicai 盡出私財). Yuan dian zhang, 334.
} 
路总管府) and all lower levels. By the 1320s, regional and local level officials no longer had the right to open granaries. ${ }^{95}$

As Shen Youliang also adds, we must take into account that both reporting policies and relief measures reflect attempts to prevent corruption and misuse of tax exemption policies and do not necessarily reflect an interest in damage mitigation. ${ }^{96}$ The extant documentation and historical reproduction of Dongming's various moriculture disasters in dynastic sources and in gazetteers of various administrative levels reflect some of the paper trails that such reporting practices left in the various administrative levels and their archives. All three of Dongming's moriculture disasters made it into dynastic accounts, but they landed in different sections. Of the three disaster records mentioned in the Dongming gazetteer's disaster section, the History of Yuan listed the 1301 incident in both the "Five Phases" (wuxing 五行) treatise and “Basic annals" (benji 本紀) with a reference to Daming prefecture (to which Dongming was subordinated), whereas the 1308 and 1314 incidents were only listed in the "Annals" but not in "Five Phases." The name Dongming was only referred to in the 1314 incident, which seems to have been the most severe since the mulberry trees were killed (shasang 殺桑). All three cases were recorded in the gazetteer of Daming prefecture (Daming $f u$ zhi 大名府 志), compiled in $1445 .{ }^{97}$ The dynastic history states that Dongming could not deliver its taxes in 1314, but does not say this for $1301 .{ }^{98}$ The report of 1314 thus can be identified as a report from the county level included as a historical event of some regional significance.

Such an interpretation allows the possibility that mid-Ming gazetteer authors may have had to rely on local sources, although, as we will see later on, we have to consider that by the late Ming dynastic historiography and prefectural gazetteers were not inaccessible and thus contents were regularly copied. In our global survey we were able to observe that 54 percent of the Yuan mulberry-related disaster reports are from (Ming and Qing) county level gazetteers, while 37 percent are from the prefecture level. That disaster events are also not consistently copied suggests that the gazetteers administrative hierarchy mirrors at least to some extent that of the Yuan administrative hierarchy of disaster relief and tax management. Two explanations for this are possible. We might assume that editors in a northern locality like Dongming, compiling a gazetteer during the mid-Ming period, were able to record information that derived ultimately from Yuan-period local (rather than central) sources. This implies that significant usable local records-or information in some form (perhaps even oral?)-survived the Yuan-Ming transition and a century or two beyond, so that it could be drawn

\footnotetext{
${ }^{95}$ Quan Yuan wen, 4.119.40. See also Da Yuan shengzheng guochao dianzhang, 368.

${ }^{96}$ Shen Youliang and Xiao Yue'e, "Yuandai shenjiang tifu zhidu yu jianzai jiuzai" also note that supervision also included the punishment of tax officials, 109.

${ }^{97}$ Dongming was subordinated to changing units but belonged to Daming after Ming rule. See China Historical GIS (Harvard University and Fudan University) records of the following number: hvd_44813. We can imagine this as a second or third wave of local gazetteer production that the Ming initiated already before the unification in 1376. Joseph Dennis, "Early Printing in China Viewed from the Perspective of Local Gazetteers," in Knowledge and Text Production in the Age of Print: China, 800-1400, edited by Lucilla Chia and Hilde de Weerdt (Leiden; Boston: Brill, 2011), 105-134, 108. Dennis's source is the preface of the Baoding junzhi 保定郡志, 1494.

${ }^{98}$ According to the Yuan shi neither could Dongming deliver in 1314 (延祐元年 [ ... ] 東明長垣等縣隕 霜殺桑果禾苗.) See Song Lian, Yuan shi, 25.564.
} 
upon by mid-Ming gazetteer editors. ${ }^{99}$ Another explanation would be that what we see here are simply the traces of Yuan hierarchies of reporting in central state archiving practices. Before we can address this conundrum, we wish to first delve a bit deeper into the question of what kind of "event" we actually see reported by inquiring into the timing of disaster records. Regulations in Yuan codices not only addressed hierarchal lines of reporting, but also how and when to report.

\section{The Rhythm of Reporting}

When treating disaster reports as "data," environmental studies have implied that the report date reflects the actual occurrence of the event. ${ }^{100}$ Following Song and Jin policies, the Yuan set reporting deadlines for disasters based on when weather had the greatest adverse effects on agriculture. Considering that weather events affect agriculture more at certain times of the year, the submission of reports on disasters were restricted to certain periods: "At all places disasters such as floods and droughts harm the fields and grain harvests. For summer fields, this concerns the fourth (lunar) month and for autumn fields the eighth (lunar) month. Untimely disasters are to be reported within a month [of the event]. Reports after this deadline will not be considered." ${ }^{101}$ Amendments to and enforcements of deadlines were made in 1282 and $1283,{ }^{102}$ when the Yuan allowed northern places such as Yulu to report into the fifth (lunar) month. In 1317 the lower Yangzi region was allowed to report up to the ninth (lunar) month acknowledging that in the South, autumn floods regularly harmed agriculture. $^{103}$

Assuming that Dongming's reporting practice followed this rule, of its three disasters in 1301 only the drought would have counted as an untimely disaster as it occurred in the sixth month (or fifth month, considering that officials had up to one month to report), whereas the moriculture failure is noted for the fourth month and the flood for the seventh month (and the latter was hence still before the eighth month and hence could be included). In the global set of mulberry-related disasters, one third (102 out of 298, 34 percent) occurred in the fourth and seventh lunar months. Seven out of ten times frosts are reported to have happened in the third month, noting a “diminishing of the mulberry yield [sunsang 損桑]." ${ }^{104}$ Nine reports mention that the mulberry tree had been killed (shasang 殺桑).

\footnotetext{
${ }^{99}$ This divergence did not converge over the centuries. Thus far, we have not found no examples of later Ming or Qing editions adding all records in the Official History of the Yuan (Yuan shi 元史).

${ }^{100}$ Wang Lige 王麗歌, “Song Yuan Jiang Huai diqu ziran zaihai de shikong fenbu tezheng yu jiben guilü” 宋元江淮地區自然災害的時空分佈特徵與基本規律, Anhui shixue 2019.2, 152-61. Peng Weiying 彭維 英, [et al.] “Hanjiang shangyou lishi shiqi handong zaihai tezheng jiqi shehui yingxiang yanjiu” 漢江上遊 歷史時期寒凍災害特徵及其社會影響研究, Ganhan qu ziyuan yu huanjing 2013.8, 83-89. Wan Honglian 萬紅蓮, [et al.], “Guoqu 2000 nian lai Shaanxi diqu bingbao zaihai jiqi dui nongye de yingxiang yanjiu” 過去 2000 年來陝西地區冰雹災害及其對農業的影響研究, Gaoyuan qixiang 2017.2, 538-48.

101 “該各處遇有水旱災傷 田粮夏田四月秋田八月非時災傷一月為限 限外申告並不準理.” Da Yuan shengzheng guochao dianzhang, 1020. It is likely that this date reflects the enthronement and rules already in place before the final usurpation of the Song. The Jin dynasty explicitly emphasized moriculture disasters, but, in general, this concerns all disasters ( $z a i)$, floods, droughts, famines, etc.

${ }^{102}$ Song Lian, Yuan shi, 12.250.

${ }^{103} \mathrm{Da}$ Yuan shengzheng guochao dianzhang, 159. All of these amendments enforce a timely response to disasters. For the former Song rule see Tuotuo 脫脫, Song shi 宋史 (Beijing: Zhonghua shuju, 2011), 172.4146, and Tuotuo, Song shi, 173.4155-4193.

${ }^{104}$ The years were 1280, 1284, 1292, 1304, 1305, 1308, 1313, 1314, 1318, and 1363.
} 
References to Dongming disasters all fit within the officially sanctioned rhythm of reporting. It is quite unlikely that "disasters"-at least if we understand them as events that were not foreseeable and in particular when we understand them as events induced by climate change and thus out of the usual rhythm of seasonal change-should consistently follow a specific human rule (unless this rule is very vague) which suggests that, rather than reflecting the date of the actual event, local gazetteer authors may have collected events and used the deadline to report all accumulated incidents. We must also consider that just as weather may be expected to induce harm within any given annual cycle, beginning with capricious periods in spring impacting sowing and the first growth period, only in late summer when harvests were brought in could any actual harm be determined-and Yuan reporting regulations reflect such considerations.

\section{Content of Reports}

As noted earlier, during our process of tagging we observed variations in the nomenclature for moriculture disasters during the Yuan and looked further at the quality of information given in local gazetteers. In this process we observed that some entries mention successive disasters, and others singular events; Big Data approaches miss this when they count each incident as a singular event.

As an illustration of how this observation may affect our interpretations, when we simply cluster all the different terms that specify "moriculture-disasters" into global full text searches, we miss the fact that the "killing of the trees" was the only event that qualified as a severe disaster, because it meant that new plantations would have to be established and no harvest could be expected for at least two years. In our interpretation, we have to consider that many other mulberry-related incidents such as "mulberry leaves were eaten (by insects)" (shisang 食桑) ${ }^{105}$ may not necessarily have constituted a major crisis, as under favorable conditions in late spring the mulberry would simply sprout new leaves and silkworms could still be fed. The degree of havoc and financial harm some of the specified events could produce varied considerably: mulberries could recover from a late frost; local officials could try to redirect harvests within a region to prevent local sericulture being impacted.

That Yuan recording practices followed this logic is likely as most of the mulberry-related disasters recorded in local gazetteers-frost (46 percent), insects (34 percent), rain (6.38 percent), or snow ( 4.36 percent), heavy winds ( 2.68 percent), or thunderstorms ( 0.67 percent) -include assessments of the degree of harm: whether mulberry seedlings, spring leaf sprouts, or entire trees were destroyed. In other such causal strings we can see the logic of cumulative effects. In Dongming's string of disasters in 1301 only the enumeration of multiple harmful incidents offers a compelling argument for the court to offer tax relief: not only had insects destroyed the mulberry

\footnotetext{
${ }^{105}$ Qiu Yunfei 邱雲飛, Zhongguo zaihai tongshi: Songdai juan 中國災害通史: 宋代卷 (Zhengzhou: Zhengzhou daxue chubanshe, 2008), 134-44. Fourteen different kinds of disasters, including water/floods, droughts, famine, insects, hail, frost, earthquakes, windstorms, snow, sanddust, rats/venom, landslides, and human and veterinary epidemics are identified by Li Tiesong 李鐵松, Ren Deyou 任德有, Zhang Xiaoxia 張曉霞, and Li Jian 李劍, “Liang Song shiqi ziran zaihai de wenxue jishu yu dili fenbu guilu” 兩宋時期自 然災害的文學記述與地理分佈規律, Ziran zaihai xuebao 2010.2, 28-32. They leave out specifications of agricultural disasters. For veterinary epidemics as another "political" disaster event during the Song, see Dagmar Schäfer and Han Yi, "Great Plans: Song Dynastic (960-1279) Institutions for Human and Veterinary Healthcare," in Animals through Chinese History: Earliest Times to 1911, edited by Roel Sterckx, Martina Siebert, and Dagmar Schäfer (Cambridge: Cambridge University Press, 2019), 160-80.
} 
leaf harvest, meaning that spring silkworms could not be raised, but subsequent droughts and floods had meant that no further silkworms could be bred that year. What we may consider then, is that when local officials decided to report disaster events, they may have bundled several events in chronological order to offer a convincing case to censors that lasting harm was done.

Our interpretation, derived from the observation of patterns around the mention of moriculture disasters, runs counter to Big Data approaches that have a tendency to itemize data into the smallest possible unit-one dataset of one event such as flood or drought-and an environmental history approach that interprets multiple disasters as an indicator of the severity of environmental changes - in which a flood, a drought and an insect plague suggest an increased degree of damage to humans ${ }^{106}$ and not a more convincing scenario for an actual disaster to begin with. It is not the singular event that should be counted as the disaster event, but only the succession of multiple incidents that constitutes one event: only the moriculture crop failure, caused by too much rain, successive insect plague and finally a drought, constitutes what we could call the causative string to substantiate one single disaster.

To focus on moriculture also means to acknowledge that disasters are always relative to their impact on humans. In principle a flood or drought only counts as a disaster when it damages human food resources, shelter, life, or economic basis. In the case of China, where disaster management was an issue of state legitimacy, prevention was an important theme. Contemporary writings on how to prevent mulberry-related disasters suggest that tax officers and censors would not accept just any damage as a disaster; officials were expected to prevent disasters and farmers to adapt to circumstances. The compilers of the Compendium on Agriculture and Mulberry Plants provided details on destructive insects' life cycles, habits, and characteristics, so that officials could both advise mulberry farmers how to avoid damage and assess whether appropriate preventive measures had been taken. The explanation was that: "At midsummer, [the insects] breed around the tree trunk on the ground. Their offspring have the form of maggots and suck the resin from the tree." ${ }^{107}$ Wang advised farmers to pick insects off their trees regularly: "a mulberry [tree or berry] cannot be free of insects. It is important to get rid of them. One can use iron wires to hook them off; or smoke them off with sulfur, so they die when they are blackened; or burn tong oil paper to block them. This is based on experience." ${ }^{108}$ Such preventive regimes emphasize that, when taken well care of, mulberry trees could develop a second growth of leaves, even after insect damage or an early frost.

It is difficult to assess whether there is a "Yuan" style in such data, given the gazetteers and the dynastic history were compiled in the early Ming. The Official History of the Yuan often specifies the financial repercussions of disasters, recording that in 1284 mulberry-related disasters harmed 30,000 households in Shandong; that, in 1305, when frost destroyed the mulberry yield in the regions around Yidu (益都) and Banyang (般陽), a total of 2,417,000 trees were killed; and that tax censors recorded

\footnotetext{
${ }^{106}$ Such interpretations of quantity increase are particularly popular in science history studies and the basis of most statistical analysis.

${ }^{107}$ Wang Zhen, Nongshu, “Zai sang” 栽桑 3.17b.

${ }^{108}$ Wang Zhen, Nongshu, “Zhongzhi pian shier” 種植篇十二 5.19b: “桑果不無蟲豆蚛務去之其法用鐵 線作鈎取之一法用硫黃及雄黃作烟薰之即死或用桐油紙燃塞之亦騐.”
} 
a loss of about 12,700 baskets of silkworms in Hejian's four counties of Qing 清, Cang 滄, Mo 莫, and Xian 獻. ${ }^{109}$

When comparing entries over time, however, different dynastic "styles" of listing disasters emerge that make the Yuan entries look sober and factual, if not "objective." Pre-Song references to disasters are historical quotes and abbreviated narratives, as in Yu Xilu's Zhenjiang gazetteer. Ming accounts increasingly address the actual damage whereas Qing disaster records increasingly narrate events and consistently specify tax relief. Dongming exemplifies these dynastic differences quite consistently, although such observations invite a close look at copying practices during the Ming era to further explore which other sources Ming editors of local gazetteers may have consulted when including Yuan disasters in their compilations. ${ }^{110}$ Before going into the issue of Ming approaches to Yuan disasters, we need to take at least a short look at the ideological and political implications in the data.

\section{Data as Discourses: Local Gazetteers and Dynastic Histories}

\section{The Mandate of Heaven in The Yuan and Ming Chapters on "Auspicious and Inauspicious Events."}

When in 1970 Herbert Franke asked how the embedding of Buddhism, portents, prophecies, and Yuan politics within the Pax Mongolica had an effect on this era's approach to environmental hazards and legitimacy, he was unable to detect the influence of either a "Mongolian" lifestyle, or a steppe or nomadic identity. ${ }^{111}$ Wang Yun exemplifies the dominance of "Chinese" voices in such debates, but also exemplifies the bias in current research on the impact of the political views on disaster studies. Yuan Chen also observes that Yuan theories of legitimacy increasingly emphasized the rulers benevolence rather than earlier notions of the cycle of five phases, area, state power, blood lines, or ethnic belonging. ${ }^{112}$ Disasters quite clearly occupied commentators of the Shangshu, as well as yin-yang specialists and diviners. ${ }^{113}$ Wang Yun thus has been studied as a contemporary politician who attempted to convince the Yuan rulers to legitimize themselves within the Chinese theory of the Five Elements and to place themselves in line with Jin-Jurchen rule. His remark on moriculture disasters is indicative of the huge ideological importance of disasters in Yuan politics for legitimacy, which has not been well researched or understood. Chen Gaohua describes Yuan emperors in his analysis of disaster politics as hands-on and practical when

\footnotetext{
${ }^{109}$ Song Lian, Yuan shi, 50.1059-60. For a detailed analysis see Wang Peihua 王培華 and Liu Yufeng 劉 玉峰, “Yuandai beifang sangshu zaihai ji guojia jiuzai jianzai duice” 元代北方桑樹災害及國家救災減災 對策, Gujin nongye 2000.1, 44-47.

${ }^{110}$ Fan Shen 樊深, Hejian fu zhi 河間府志 (1540; repr. in Tianyige cang Mingdai fangzhi xuankan 天一 閣藏明代方志選刊. Taibei: Xinwenfeng chuban gongsi, 1985), “Fengtu zhi: Xiang yi” 風土志: 祥異 7.22b$26 \mathrm{~b}$.

${ }^{111}$ Herbert Franke, From Tribal Chieftain to Universal Emperor and God: The Legitimation of the Yuan Dynasty (München: Verlag der Bayerischen Akademie der Wissenschaften, 1978). See also Wei Chongwu 魏崇武, “Lun Meng Yuan chuqi de zhengtong lun”論蒙元初期的正統論, Shixueshi yanjiu 2007.3, 34-43.

${ }^{112}$ Yuan Chen, "Legitimation Discourse and the Theory of the Five Elements in Imperial China," 349.

${ }^{113}$ This includes literati scholars such as Wang Tianyu 王天與, or Dong Ding 董鼎, or specialists of the Shangshu 尚書 such as Chen Li 陳櫟 (1252-1334), Zhao Fang 趙汸 (1319-69) or Zhu Zuyi 朱祖義 (Yuan). For the general role that weather forecasting and astrological-astronomical concerns played in these debates in imperial China in general see David Pankenier, "The Cosmopolitical Background of Heaven's Mandate," Early China 20 (1995), 121-76.
} 
responding to disasters. Comparing them to Song rulers, he identifies them as quite hostile towards the political scheming of Chinese local officials. ${ }^{114}$ Any historical analysis of Chinese sources has to recognize that Ming scholars and politicians molded the historical image of their predecessors on many levels. The Ming founder, Zhu Yuanzhang (1328-98), primarily had the Yuan history compiled to authorize his own rule, asking editors "not to add any appraising remarks, but write in a straightforward manner, forget about formalities so as to let the evil shine through." ${ }^{115}$ Geoffrey Humble has identified such editorial policies in the biographical sections suggesting this might be applicable for the other sections as well. ${ }^{116}$

Quantitative data have informed most conclusions about the environmental footprint of the Yuan, yet a close reign-by-reign view of moriculture disasters in northern local gazetteers illustrates the overwhelming dominance of Neo-Confucianism in the Yuan period and its growing impact in that of the Ming. For instance, during the nineyear reign of Emperor Renzong-who reduced taxes and occasionally listened to Song-Confucian Chinese advisers-only one moriculture disaster was documented, whereas disaster references not unsurprisingly increased during the reign eras of aggressive or unruly emperors.

When comparing Yuan and Song dynastic histories, Gong Guanming and Yang Wansheng observed that statistically moriculture disasters were reported with a lower frequency during the Northern Song than the Yuan. Between 962 and 1191, ${ }^{117}$ they identified 16 mulberry disaster reports to the Song court, on average once every 14.4 years. During the 93 years of the Yuan rule, between, 1271 and 1363, 40 mulberry-related disasters reached the court, on average once every 2.5 years and thus six times more often than during the Song. ${ }^{118}$ However, close scrutiny shows that the Song often listed moriculture disasters around important political events such as the loss of the north. The Yuan, by comparison reported disasters quite regularly, and often in the same places. Dongming illustrates that once a local gazetteer included disaster records, succeeding editions continued to chronicle such disasters. During the 90 years of Yuan in total 28 disasters are mentioned in the Dongming gazetteer, an average of once every 3.2 years. Whereas, as Gong and Yang also observed, more disasters are recorded in texts for the Yuan period than for the Song. If we now compare forward in time, we can see that during the 277 years of the Ming there is a total of 80 disasters, which also gives an average of once every 3.4 years. From a Big Data and long-durée viewpoint, disasters did not hit Dongming particularly hard during the Yuan rule. Or we could simply say that compilation practices were consistent over time.

Cross-dynastic analysis reveals other important differences in the styles and content of disaster records. In comparison to the Ming and Qing, Yuan records are quite plain, consisting mainly of dates and disaster kinds which led Luo Lin to identify them as reliable and objective. This still is apparent in the Qing gazetteer of Dongming, for

\footnotetext{
${ }^{114}$ Chen Gaohua, "Yuandai zaihai fasheng shi gaishu," 52-77.

115“不作論讚 但據事直書 具文見忘 使共普惡自見.” Song Lian, Yuan shi, “Zuanxiu Yuan shi fanli” 纂修元史凡例, 4675 .

${ }^{116}$ Humble, "Princely Qualities and Unexpected Cohenerce," 336.

${ }^{117}$ Gong and Yang begin prior to unified rule and beyond the Jianyang rupture, implying that such disaster policies in the case of the Song state, as with Yuan rule, did not entirely comply with the unification of dynastic territory. Gong Guangming 竟光明 and Yang Wangsheng 楊旺生, “Song Yuan Liangchao sangzai bijiao” 宋元兩朝桑災比較, Nongye yu jishu 2006.6, 90-97.

${ }^{118}$ Gong Guangming and Yang Wangsheng, “Song Yuan Liangchao sangzai bijiao," 90.
} 
instance, whereas Ming and Qing entries also contain other information, such as amount of granted tax relief. Differences in content illustrate that much had changed even as the structure of local gazetteers was continuous. In contrast to Yu Xilu who had quoted very few categorical disasters in Zhenjiang's gazetteer prior to the Yuan and stopped with reports of the Tang era, the extant Kangxi (1673) and Qianlong editions (1756) of the Dongming gazetteer offer a chronological overview of reporting styles. As sampling from both southern and northern regions shows, Ming editors of local gazetteers began listing disasters up to their own life time, often up to the actual publication date of the local gazetteer, ${ }^{119}$ as did most Qing editors. ${ }^{120}$ From the Yuan to the Qing, a miscellanea of historical information with practical implications thus was turned into a historical collation of precedents of administrative and political decisionmaking for practical use.

\section{Consistency in Datasets: The North and Moriculture Disaster Events}

As historians we learn that, whereas dynastic historiography may have tended to smooth out regional variations, local gazetteers provide us with insights into local conditions, sometimes even allowing us to see how such conditions changed dynamically over time. One might expect that datasets derived from local gazetteers would reflect either the local patterns of editorial rules or syntactical choices. A statistical analysis of tables of contents shows that local gazetteers in some of these Northern regions favored certain categories. Further research on prefaces and postfaces in gazetteers and the content of specific sections is necessary before we can determine if such patterns resulted from a regional preference or administrative guidance. ${ }^{121}$ Local gazetteer records of Yuan moriculture disasters occur all across the north and hardly at all in the south (Figure 5). This is the case even though, as Fan Jinmin noted, the lower Yangtze region became the major center of silk production during the Ming, which would give local officials an interest in conveying moriculture-related information and disasters to "order the past for future use." ${ }^{22}$ Ming literati in southern regions could often rely on still extant earlier copies of local gazetteers and we may assume that the conditions of local archives in the different regions of Ming China was different too, with northern

\footnotetext{
${ }^{119} \mathrm{Wu}$ Fengxiang 吴鳳翔 and Li Shunming 李舜明, Chongxiu Wuxi Xianzhi 重修無錫縣志 [1496; repr. in Zhongguo difangzhi jicheng 中國地方誌集成] Nanjing: Fenghuang chubanshe, 2004). In chapter Xiangyi 祥異 disasters recorded up to 1496, 27.1a-4b. Huang Zhongzhao 黃仲昭, Baimin tongzhi 八閩通 志 [明弘治 r. 1488-1505; repr. in Siku quanshu cunmu congshu 四庫全書存目叢書] Jinan: Qi Lu shushe, 1996), chap. Xiang yi 祥異, disasters recorded up to 1486, 81.1a-26a. In Han Sizhong 韓思忠, Zhengde Zhongmou xian zhi 正德中牟縣志 [1515; repr. in Yuan Guoli Beiping tushuguan jia ku shanben congshu 原国立北平图书馆甲库善本丛书] Beijing: Guojia tushuguan, 2013), chap. “Zaiyi” 災異 did the same (no historical disasters; only the ones from the Ming, up to Chenghua 成化, two reigns earlier), 1.8b. An Du 安 都, Jiajing Taikang xian zhi 嘉靖太康縣志 [1524; repr. in Tianyige cang Mingdai fangzhi xuankan xubian 天一阁藏明代方志选刊续编] Shanghai: Shanghai shudian, 1990), chap. “Wuxing”五行 4.12b-16b did the same (historical disasters up to the same reign; but under Guochao 國朝 disasters are organized categorically rather than chronologically).

${ }^{120}$ Dongming xian zhi, the Kangxi edition recounts disasters until the year it was published in 1673 (Kangxi 11), “Nianji zaixiang” 年紀灾祥 7.2a-15b and Qianlong until 1753 (Qianlong 18), “Nianji zaixiang”年紀災祥 7.2a-14b.

${ }^{121}$ Chen Shih-pei, "What One Should Know about a Locality: Analyzing Knowledge Categories in Chinese Local Gazetteers," in a forthcoming publication edited by Huiyi Wu and Mackenzie Cooley.

${ }^{122}$ Fan Jinmin, Yibei tianxia, 68-82.
} 


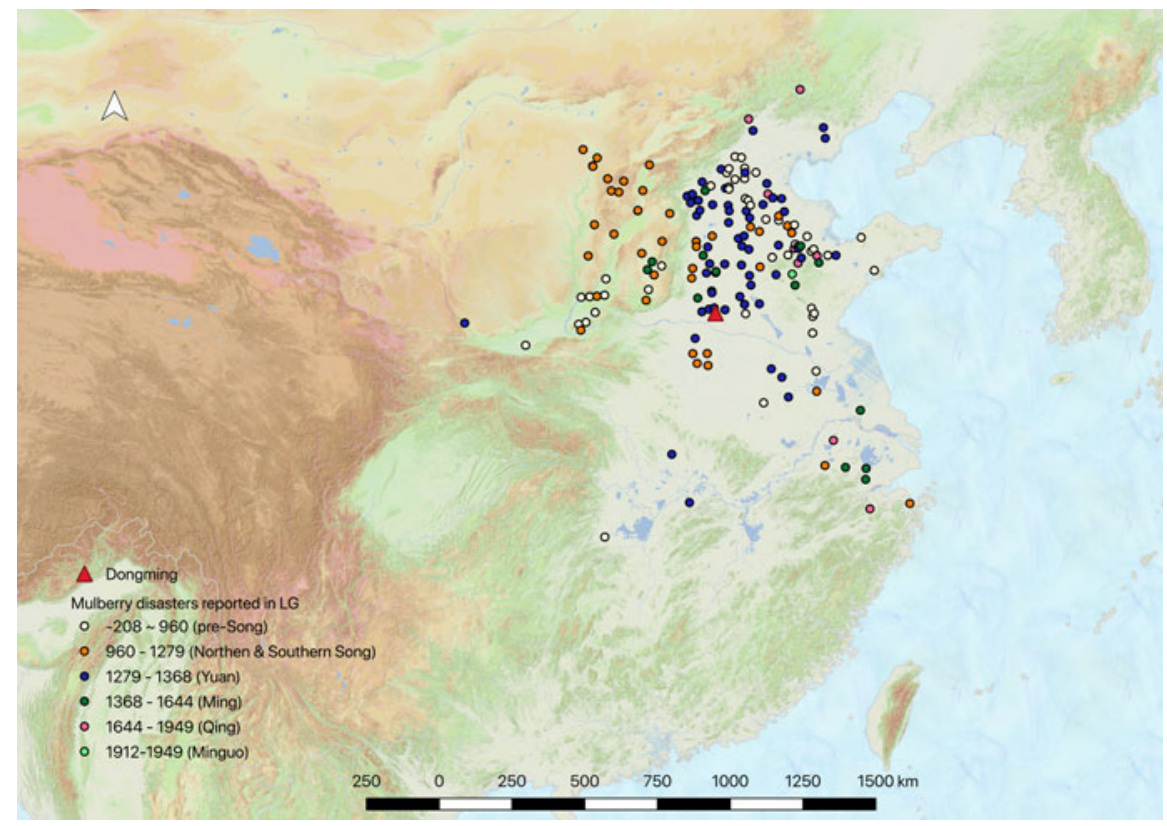

Figure 5. Geographical Distribution of the 404 Reported Mulberry-Related Disasters, Mentioned in 3,999 Local Gazetteers, Color-Coded With the Time Periods They are Dated. Map by Lin Nungyao.

regions presumably being more impacted by war and destruction. And still it is mainly northern mid-Ming and later gazetteers that report on moriculture disasters. Xu Guangqi 徐光啟 (1562-1633) identified a similar bias in dynastic records towards insect and moriculture incidents. ${ }^{123}$

Should we assume that moriculture in the south was stable and less affected by weather than in the north? Fan Jinmin, for instance, who has amply emphasized the rise of sericulture production in Jiangnan by the Ming era, notes indeed that summer taxes of juan-silk in Jiangnan during the Yuan were partly even higher than the Song and definitely higher than the Ming. While these numbers indeed manifest the presence of private tax-silk weaving in this region, we must read them in the context of other policies that targeted the introduction and expansion of the trade, as testified by continuous complaints by contemporary local worthies. ${ }^{124}$

\footnotetext{
${ }^{123}$ Xu Guangqi, Nongzheng quanshu, "Huangzheng" 荒政 44.988. Xu Guangqi then puts this into a rule: "The south has gloomy places, Changjiang and Huaihe rivers flow in the north. Lush greens are in the West and the Liang and Song eras opened the soil in several prefectures of the East. Ponds and lakes spread out expansively; when overflows are impermanent, they call it dried up lakes. Here the locust is born. All historical records are like this.” See Wang Peihua, Yuandai beifang zaihuang yu jiuji. See also Zheng Peng 鄭 鵬, “Weiji yu yingdui: huangzai zhong de Yuandai guojia" 危機與應對: 蝗災中的元代國家, Luojia shiyuan (2013), 125-52. See also Zi Qing 自慶, 'Zengxiu Jiaoyuan qinggui' shidu “增修教苑清規” 釋讀, translated and explained by Xin Hao 心皓 (Shanghai: Shanghai guji chubanshe, 2015), "Qianhuang" 遣蝗, 74 .

${ }^{124}$ Fan Jinmin, Yibei tianxia, 38-39, see also his comparison of taxes on page 16. These numbers are actually misleading, as they must be read against a changing tax system. By the Yuan juan-silk no longer functioned as a monetary item (and was replaced with paper, then copper etc.), and the use of cotton as a
} 
Are such geographic patterns caused by environmental patterns; are they the result of contemporary policies, or simply an artefact of textual transmission? Working under time pressure, the editors of the History of the Yuan mostly relied on the archives at the former Yuan capital, Beijing and the vicinity. One important reason why local gazetteers as a genre amplified, rather than nuanced, regional coverage, is the loss of local archival records due to warfare during the Ming conquest which impacted localities in the northern regions hard. We need to keep in mind that quirks in textual transmission shaped datasets and that the very structure of the genre, and varying applications of "editorial rules" also had an effect. For instance, Ming and Qing local gazetteer editors begin with 1276, the first year when the Yuan had successfully conquered the Song and proclaimed the unification of the territory. Some disaster references in the History of the Yuan such as Li Dehui's 李德辉 (1218-?) report about moriculture disasters in 1270, are omitted in Ming local gazetteers, probably because of formal reasons. ${ }^{125}$ Comparing datasets also indicates that by mid-Ming times, when editors in general remained faithful to the historical nature of the chapter on "auspicious and ominous events” (xiangyi 祥異), they got their information from the Official History of the Yuan at least as often as from archival records.

For the Yuan, 87 out of 208 location-based records of mulberry disasters actually match the records in the History of the Yuan, with a small number being traceable in other dynastic compilations, such as Ma Duanlin's 馬端臨 (1245-1322) Comprehensive Study of Literary Remains (Wenxian tongkao 文獻通考, compiled ca. 1317). The regional focus of Yuan moriculture disasters in local gazetteers matches that of the History of the Yuan which also contains references to the regions of Hebei (38.5 percent), Shandong (44.4 percent), Henan ( 8 percent) and Shanxi (9.1 percent) (see the black crosses in Figure 6). ${ }^{126}$ More surprising is how that matches the regional distribution of all other disasters specifying weather events that are listed in dynastic history regardless of kind, despite the wide geographical spread of locations (see in Figure 6 the heat map and red points respectively). Even though both the dynastic historiography of the Ming and Qing as well as private writings occasionally note moriculture disasters in the south, until the 1880s local gazetteer editors identified the south as a pristine region, keeping this region-at least in the historical view of the genre-free from any disaster-events. ${ }^{127}$

It is more difficult to substantiate the environmental causes of disasters. In her survey of dynastic accounts, Wang Peihua, relying on the same data as Xu Guangqi in the

textile for commoners was popularized. Ming provisioned raw silk and high-end silk threads for its stateowned production and not cheap tax-silk. Dagmar Schäfer, Des Kaisers seidene Kleider (Heidelberg: Edition Forum, 1998). The Daming yitong zhi 大明一統志, published in 1461, and Li Hongzhang 李鴻章, Jifu tongzhi 畿輔通志 [originally published in 1683 and revised in 1735; 1884; repr. in Zhongguo difangzhi $j i$ 中國地方志集] Nanjing: Fenghuang chubanshe, 2010) contain no moriculture disasters at all, which suggests a substantial shift in disaster policies.

${ }^{125}$ Song Lian, Yuan shi, 162.3812. Su Tianjue 蘇天爵, Yuanchao mingchen shilüe 元朝名臣事略 (Beijing, Zhonghua shuju, 1996), 212-17 and “Zuocheng Li Zhongxuan gong” 左丞李忠宣公 13.259-264.

${ }^{126}$ Jiang Ying, Shandong sichou shi, 197. See also Fan Jinmin, Yibei tianxia, 36-38.

${ }^{127}$ Only two local gazetters of the late Qing identify mulberry disasters in the North retrospectively: Wu Lufu 吳履福, Miao Quansun 繆荃孫 [et al.], Changping zhouzhi 昌平州志 [1939; repr. Zhongguo fangzhi congshu 中國方志叢書] Taibei: Chengwen, 1968), “Dashibiao” 大事表 6.1a-13b. Zhou Jiamei 周家楣 [et al.], Guangxu Shuntian fu zhi 光緒順天府志 [1889; repr. in Xuxiu Siku quanshu 續修四庫全書] Shanghai: Shanghai guji chubanshe, 2002), “Gushi zhi” 故事志 69.9a: “Mulberry trees were killed” (大德九年春二月 [1305/2]: 殺桑). 


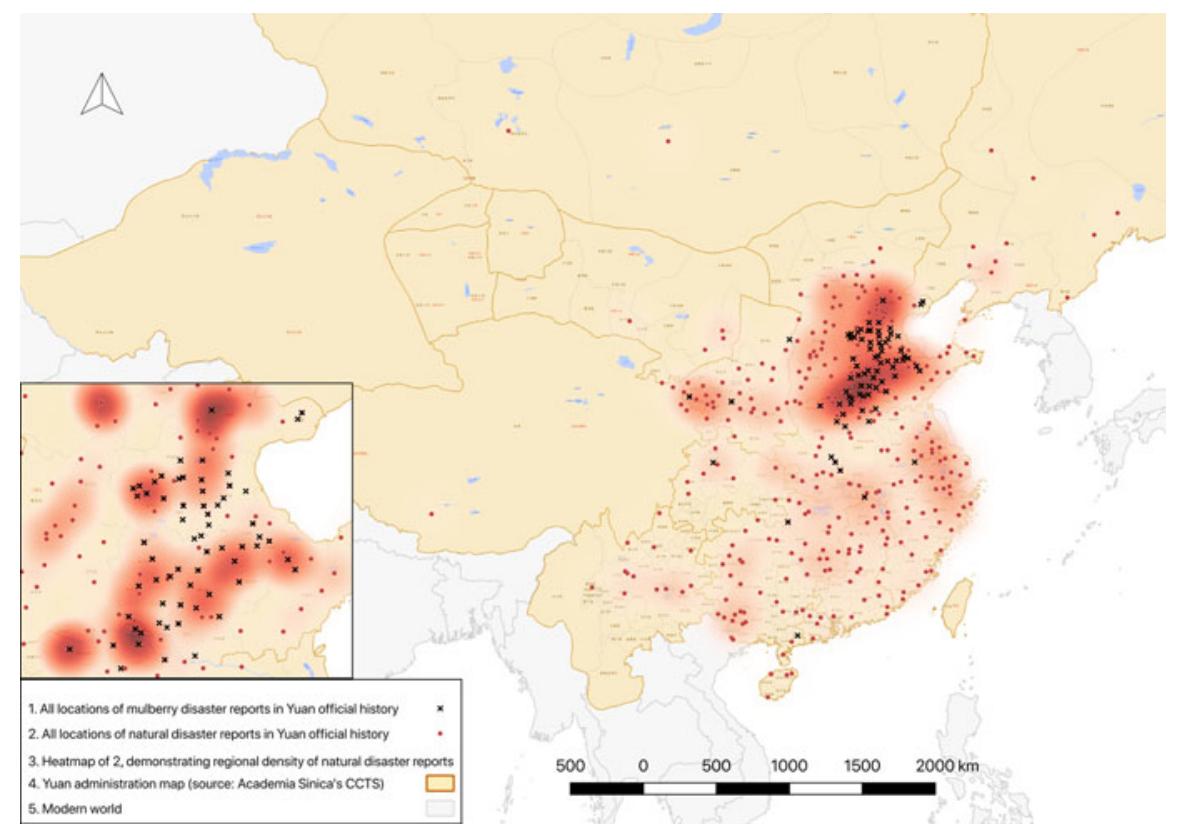

Figure 6. Locations of Natural Disaster Reported in the Yuan Dynastic History (Yuan Shi and New Yuan Shi). The mulberry disaster reports are highlighted as black crosses. The background heat map reflects the number of natural disaster reports in each locales. Data curated by Lin Nungyao, Hung Yi-Mei, Su Hong-Ting, and Liu Yuxin; map by Lin Nungyao.

seventeenth century, concluded that regions between the thirtieth and fourtieth parallels of latitude were reported as suffering mainly from insect plagues, frost, or snow damage, with few references to wind and rain. ${ }^{128}$ Dongming is within this region, yet as our mapping makes apparent, not all localities that produced mulberry in this zone reported such events. In contrast to Wang Peihua's thirty to forty degree zone, gazetteers suggest that Shandong province suffered more from frost and less from insects, the opposite being true for Hebei province. Other interesting effects are that Hebei, Shanxi, and Shandong, the three provinces on the Huabei plain accounted for most of the moriculture disasters. As for the temporal proportion distribution, Hebei and Shandong gazetteers have similar structures: for moriculture disasters, both include more reports from the Yuan than any other era. In Shanxi, which reported fewer incidents than the other two regions in general (even though it had more reports prior to the Ming), all references to disasters relate to the Western Jin, Eastern Jin, and Northern Song; there are no reports from the Yuan. In Beijing, Tianjin, Shandong, Jiangsu, Hebei, and Hubei, records from the Yuan are dominant, whereas Anhui and Henan provinces have a lower proportion of Yuan records, but do have reports from the Song and Ming periods. Twenty-five of the thirty-two reports from the Ming period come from Anhui, Shanxi, Henan, Shandong, Hebei, and the lower Yangtze region (by the Ming part of Northern Jiangsu), all places that had traditionally cultivated mulberry up until the Yuan period,

${ }^{128}$ Wang Peihua, Yuandai beifang zaihuang yu jiuji, 165-68. 
but ceased to be prime centers of the silk industry during the Ming period when central Jiangsu and Zheli became the major coastal centers of silk production.

Such patterns cannot be easily explained as they result from the status of sericulture across time and space, as well as the commercialization of mulberry leaves, changing tax collection methods, changing policies that once centralized and then again localized control over disaster management and tax relief. Further research is necessary as some of these patterns suggest that social networks may have played a role through which editors negotiated how to compile local gazetteers and what role they thought disasters should play herein. Another important influence observable in Big Data sets is emulation: once a local gazetteer listed moriculture disasters, succeeding editors continued to account for such disasters, tracing incidents as far back as they could. Such efforts differed in quality. While the local gazetteer of Huzhou prefecture (Huzhou fu $z h i$ 湖州府志) only included records from the Ming and Qing, that of Zouping county (Zouping xian zhi 邹平縣志) started in the Western Jin, and then jumped back to the Guangxu (1871-1908) and Xuantong (1909-11) reigns in Qing, leaving a 1,600-year gap. Further research is necessary to substantiate how far topography may have created different weather effects-along river banks east of the Shandong mountain ranges and on the Huabei plateau that indeed are also reflective of micro-climatic environmental conditions. Nuanced mapping also suggests that other factors should be taken into account, including that social networks may have taken a fancy to devaluing the Yuan by commemorating its failures and disasters.

\section{Digital Humanities, Local Gazetteers, and Disaster Regimes: Towards a Conclusion}

Historical research relies on a vast array of methods-hermeneutics; and enriching or limiting this toolkit inevitably also limits, defines, or enriches the results. When pursuing research on one local gazetteer, scholars are able to give a nuanced account, but are limited by their capacity to take other texts into account and thus extrapolate from the particular case. Readers-in dynastic times mostly from the same scholarly elite as editors, later on twentieth-century scientists such as Zhu Kezhen and modern historiansrelied on their understanding of the local gazetteers as sources as verified historical facts and collected information and interpreted data for statistical and spatial analyses of disasters based on their understanding of the local gazetteers meaning-giving subcategories-the syntax of the local gazetteers. ${ }^{129}$ Whereas early Big Data analysts suggested that idiosyncratic cases would be compensated for by Big Data-that is, multiple mentions would identify the severity of an event, LoGaRT allows analysts to combine both views and to address local gazetteers in their digitized sum as a source. LoGaRT has been built primarily to enable the genre itself to be examined: how individual or communal a practice such as disaster control was, whether a locality set standards, adhered to them or ignored them. By enabling analysts to switch between a bird's eye Big Data view and a close reading of an individual case, LoGaRT helps researchers to generate

\footnotetext{
${ }^{129}$ In Zhu Kezhen 笈可楨, “Zhongguo jin wuqian nian lai qihou bianqian chubu yanjiu” 中國近五千年 来氣候變遷的初步研究, Kaogu xuebao 1972.1, 15-38. Zhu identified 1400-1900 as LG era and exemplified a couple of "unusual weather" records, such as lake freezing events, which can be found under the respective sub-chapter heading. For an overview of such collations of data see Lai Xinxia 來新夏, Zhongguo difang zhi 中國地方志 (Taibei: Shangwu yinshuguan, 1995), 179-80. See also Andrea Janku, “Heaven-Sent Disasters." For an example of mapping, see Chen Zhengxiang 陳正祥, Zhongguo wenhua dili 中國文化地理 (Beijing: Sanlian shu dian, 1983), 23-58.
} 
new research questions, some of which cannot be addressed by analog means. First and foremost, it allows us to study how local gazetteers emerged and grew and what effects they had.

Local gazetteers, for all their heterogeneity, provide an important source of information about localities-deliberately arranged and strategically organized. With regard to disaster records the geographies and chronologies derived from local gazetteers can only be understood as the historical product of textual transmission, in which some information was preserved and some lost. But we have also to consider that local gazetteers were by definition "working documents" that people regularly consulted and used to construct senses of local identity, belonging, and history. They were important for the regulation of trade, local society, and the local economy; they were scholarly works-"books for remembering the past and understanding when and how things in the present came to be known as they were." 130 Their contents helped shape local and imperial views.

When Yu Xilu in the Yuan era added a subsection on disasters, he may have acted on a personal whim. But even if we find regional trends in compilation styles and disaster management, local gazetteers cannot be considered innocent, seeing that by the mid-Ming period mainly editors in the north included Yuan disaster reports systematically into their disaster sections. Political power mattered in China's history of disasters, or, as Hsu Cho-yun put it in 2000: "since the imperial reign environmental changes are suggestive of the success and failure of politics" and "human efforts and weather are seen in relation to each other." ${ }^{131}$ It is thus crucial to see that disasters were political on all possible levels: as they happened, were observed, valued, named, classified, administered, recorded, and retrieved from any dynastic, bureaucratic, or imperial record. This inevitable relation to power also means that any notion of an environmental condition as "given" or inevitable, or harmful, or a product of warfare, settlement, or cultivation was inherently political too. This means that landscapes accessed through texts are mediated by politics and scholarship. ${ }^{132}$

Each genre fulfilled a role in this meaning-making. Agricultural tracts (nongshu 農書) and seasonal calendars recorded weather events while individuals reflected on practices and concepts of weather also in their private writings or in novels and poetry. Court historiographers established precedents and formed politics and regulations that each succeeding dynasty consulted, even if they broke with tradition. In China's vast literature, local gazetteers were reflective of local and central state approaches and at the same time also reveal nuances of individual and regional awareness, how one knew, retrieved, and used historical disasters. This genre hence has preserved and reveals the changing historical awareness of disasters, or what Yves Citton has termed

\footnotetext{
${ }^{130}$ Bol, "The Rise of Local History," 14.

${ }^{131}$ Cho-yun Hsu, "Chinese Attitudes Toward Climate," in The Way the Wind Blows: Climate Change, History, and Human Action, edited by Roderick J. McIntosh, Joseph A. Tainter, and Susan Keech McIntosh (New York: Columbia University Press, 2012), 209-20.

${ }^{132}$ Ruth Mostern, Dividing the Realm in Order to Govern. Ruth Mostern, "Sediment and State in Imperial China: The Yellow River Watershed as an Earth System and a World System," Nature and Culture 11 (2016), 121-47. David Biggs, "History and the Militarized Landscape: Long Historical and Broad Social Views," in Nature and History, edited by Mahesh Rangarajan and Gunnel Cederlöf (Oxford: Oxford University Press, 2017), 162-84 shows how South-East Asia’s changing political forces defined coastal varyingly as unused lands. In addition, historians such as J. Schlesinger have recently complicated the notion of wild, pristine, or natural lands. Jonathan Schlesinger, World Trimmed with Fur: Wild Things, Pristine Places, and the Natural Fringes of Qing Rule (Stanford: Stanford University Press, 2017).
} 
an ecology of attention (“écology de l'attention") when describing capitalism, overabundance, and advertising in our modern world. Citton is mostly interested in this mechanism within capitalism and an "economy" of the modern age, but we suggest that his definition also describes the historical role and modus operandi of local gazetteers and the transformations in attention and distraction that they reflect within epistemic (how to know) or political regimes.

As each local gazetteer was meant to resonate, in structure and content, with other local gazetteers, the genre offered its own ecology, that is, "a vital communicational milieu." 133 This milieu functioned, even if individual compilations deviated from any given norm, because sections such as "auspicious events and disasters" proliferated over time. LoGaRT enables us to look at how, as the genre emerged and multiplied, local gazetteers created one layer of attention that existed in a larger ontology of visibility, how it reflected local knowledge about weather and disasters and how they created or recognized the locally known. In this combined analysis of events and structures of disasters, we see local gazetteers' approaches to disasters emerging as a Foucauldian dispositif: they represent a network of information on tactics, institutional processes, and local subjectivities exerting power. Disaster records are heterogeneous artifacts of local and imperial discourses, regulations, material practices of archiving, documenting, and narrating disasters and the history of a place, both the product of an individual effort and a collective enterprise. Through their appearance as local knowledge, local gazetteers' disaster records were facilitating public action. Tracing their historical reproduction suggests that these data were continuously feeding into scholarly discourses about the political role of the Yuan and what a disaster was-even though more research is necessary to understand its effects and nuances at different points in time. Part of understanding this discourse is to follow the lines of textual transmission that have left us with fragments rather than a complete set; regional variety rather than imperial unity. LoGaRT allows us to follow strategies for anchoring imperial politics locally and imperializing local political insights through time. For instance, using computational methods to examine both syntax and style, we can see that whereas no other Yuan editor followed Yu Xilu, later in the Ming and Qing periods others described mulberry sang in "local product" sections and juan-tax silks in "tax" sections. These examples are mostly found in the gazetteers of regions that were unfamiliar with this practice, such as Gansu, or the island of Hainan around the fourteenth century, and they proliferate at times when the empire invested in this trade region: for example when the Ming Wanli (1563-1620) and Chongzhen (1611-44) emperors promoted sericulture around Beijing in the seventeenth century, or when the Manchu-Qing emperors Kangxi (1654-1722) and Qianlong (1711-99) were attempting to revive sericulture in northern regions.

Various researchers, emphasizing the importance of local gazetteers, have shown that this genre and each of its parts varied with intellectual trends and individual positions. However, if we take seriously local gazetteers as working documents, then their role goes beyond that of a product: they themselves, must be understood as a constituent part of China's intellectual life-an intellectual stance on "local knowledge." Documenting historical disasters in local gazetteers has underlying dynamics that shed new light on efforts by Chinese scholarly and state elites to localize information for use. And such disaster records are indicative of an epistemological practice-of how to know locally. This by itself may not be surprising, except when compared

${ }^{133}$ Yves Citton, The Ecology of Attention, translated by Barnaby Norman (Cambridge: Polity, 2017), 74. 
with other intellectual traditions or a modern approach to the "local" as an analytical category. Scholars in the past, by generating and using this genre, constituted "local knowledge" through action. While China's intellectual elites when authoring local gazetteers produced an ecology of imperially visible localities and local knowledge, readers and users of the same class assessed such information-gathering efforts as a necessary but minor residue of governance practices, up until the mid-Qing intellectually relevant only to the minor man (xiaoren 小人). For the intellectual elites of the Ming, for instance, “native” (ben 本, tu 土), or “indigenous” (gen 根) and local (difang 地方) information belonged in the category of customs and habits ( fengsu 風俗), not knowledge ( $z h i$ 知) or wisdom ( $z h i$ 智). While, by the late seventeenth century, local gazetteer authors occasionally introduced categories such as "local languages" (or dialects tuyan 土言), Liang Qichao anchored his approach to "local gazetteer studies" to intellectuals such as Gu Yanwu 顧炎武 (1613-82), who began taking an interest in "daily knowledge” (rizhi 日知), or Zhang Xuecheng 章學誠 (1738-1801), who utilized regional trends to criticize certain trends at the Qing court. ${ }^{134}$

We could thus say that historical Chinese actors-in contrast to modern historical approaches since Geertz-long denied "local" any analytical purpose in intellectual life and evidently when defining what knowledge was. Or we could see that from a historical view, local gazetteers represent a different epistemological approach, one that dynamically created an epistemology-in-action. For a historical approach, especially when pursued with Geertz's anthropological method in mind, the "local" has to be considered in all its dynamics: as it was practiced and as the concept came into use in China's intellectual life. When modern sociological theory-not only in Chinese and China-foregrounds the analytical purpose of the "local" or works with neologisms of the "situated," or "localized" to assess historical accounts of knowledge-making, it neglects the huge impact that local gazetteers had and still have. A chance lies in such historical cases to refine and sophisticate an important analytical category.

In a genre-specific view, historical notions of Yuan rule as a particularly disastrous time emerge as the product of Yuan disaster reporting practices and Ming and Qing data collection efforts, impacted by broken lines of transmission, political machinations, and individual choices. What may be even more important though, as Citton further helps to highlight, is how the local gazetteers as epistemology-in-action first created a collective public for Yuan disasters and then by the twentieth century slowly achieved the status of "l'ontologie de la visibilité qui mesure le degré d'existence d'un être à la quantité et à la qualité des perceptions dont il fait l'objet de la part d'autrui" (the ontology of visibility, which measures a being's level of existence by the quantity and quality of its perception by others). ${ }^{135}$ When modern historian David Morgan stresses "that the mid-fourteenth century was a difficult time in many parts of the world; Mongol China

\footnotetext{
${ }^{134}$ See Gu Yanwu 顧炎武, “Ying Ping er zhou shishi xu” 營平二州史事序, in Gu Yanwu wenxuan 顧炎 武文選, edited by Gu Yanwu 顧炎武 (1659; repr. in Ming Qing ba dajia wenxuan congshu 明清八大家文 選叢書. Suzhou: Suzhou daxue chubanshe, 2001), 35-38. See also Zhongguo fangzhi tongjian 中國方志通 鑒, edited by Zhongguo difangzhi zhidao xiaozu 中國地方志指導小組 (Beijing: Fangzhi, 2010), vol. 2, 1038; Christine Moll-Murata, Die chinesische Regionalbeschreibung: Entwicklung und Funktion einer Quellengattung, dargestellt am Beispiel der Präfekturbeschreibungen von Hangzhou (Wiesbaden: Harrassowitz, 2001), 15. Liang's generation usually took recourse to Gu's Tianxia junguo libing shu 天 下郡國利病書 of 1662. Zhang Qiong sees the changing techniques of these eras in relation to Jesuit influences. Zhang Qiong, Making the New World Their Own: Chinese Encounters with Jesuit Science in the Age of Discovery (Brill: Leiden 2015), 264-67.

${ }^{135}$ Citton, The Ecology of Attention, 74-75.
} 
suffered as much as anywhere, being afflicted with a variety of natural disasters-especially floods and pestilences" or Tsai sees that environmental pressure across the continents "opened the way for disorder on a massive scale"; ${ }^{136}$ or when Chinese climate scientists ponder a possible early Asian beginning of a Little Ice Age, they assign “zai" (災), a "natural” character beyond Yuan-contemporary notions of human responsibility and counteraction, and have awarded an ontological status to the local gazetteers and its data and no longer see an epistemology-in-the-making. Only because these groups assign local gazetteer disaster records the status of truth, reality, or facts can they provide data for ontological claims on historical climate change.

The digital datasets created in this research themselves suggest that many assumptions about local gazetteers require further research. This includes how local gazetteers spread and expanded from the Song to Yuan Dynasty or how their references to disasters and tax accounts varied regionally and how historiographically local gazetteers as a genre have shaped 1980s assumptions about economic and Malthusian population in China. ${ }^{137} \mathrm{DH}$ methods that help researchers address structural issues and content have here been employed to illustrate a genre-specific analysis on China's disaster history. China's disaster literature, unlike the Hapsburg case mentioned earlier, not only offers a longue-durée construction of weather reports, but maybe a genre-specific one too, one in which dates, localities, and degree of severity may have been reliably recounted-yet, as much as this was "imperially observed," it only became a fact very late, when it was "locally made true."

\footnotetext{
${ }^{136}$ David O. Morgan, “The Decline and Fall of the Mongol Empire," Journal of Royal Asiatic Society 19 (2009), 434. Wei-chieh Tsai, "Ethnic Riots and Violence in the Mongol Empire: A Comparative Perspective," Mongolian Studies 33 (2011), 96.

${ }^{137}$ The literature on this topic is too vast to recount here; especially if one includes debates that see climate in general as a motor of political history, the creation of wealth, and the 1970s discussion on Malthusian growth. An early example of a longue durée correlation within climatic models is Pao-kuan Wang, "On the Relationship between Winter Thunder and the Climatic Change in China in the Past 2200 Years," Climatic Change 3 (1980), 37-46. See also an early longitudinal study anticipating further work on China's environment by Peter C. Perdue, Exhausting the Earth: State and Peasant in Hunan, 1500-1850 (Cambridge: Harvard University Asia Center, 1987); Other examples include Jared Diamond, Guns, Germs, and Steel: The Fates of Human Societies (New York: W.W. Norton, 2017); Robert Marks, The Origins of the Modern World : A Global and Environmental Narrative from the Fifteenth to the Twenty-First Century (Lanham: Rowman \& Littlefield, 2019); Mark Elvin, Retreat of the Elephants: An Environmental History of China (New Haven: Yale University Press, 2008).
}

Cite this article: Schäfer D, Chen S, Che Q (2020). What is Local Knowledge? Digital Humanities and Yuan Dynasty Disasters in Imperial China's Local Gazetteers. Journal of Chinese History 4, 391-429. https://doi.org/10.1017/jch.2020.31 